\title{
Extracellular membrane vesicles and immune regulation in the brain
}

\author{
Chiara Cossetti, Jayden A. Smith, Nunzio Iraci, Tommaso Leonardi, Clara Alfaro-Cervello and \\ Stefano Pluchino*
}

Cambridge Centre for Brain Repair, Department of Clinical Neurosciences, Stem Cell Institute, University of Cambridge, Cambridge, UK

\section{Edited by:}

Claudia Verderio, Università di Milano,

Italy

\section{Reviewed by:}

Roberto Furlan, San Raffaele

Scientific Institute, Italy

Giovanni Camussi, University of

Torino, Italy

\section{*Correspondence:}

Stefano Pluchino, Cambridge Centre

for Brain Repair, Department of

Clinical Neurosciences, Stem Cell

Institute, University of Cambridge, ED

Adrian Building, Forvie Site, Robinson

Way, Cambridge CB2 OPY, UK.

e-mail:spp24@cam.ac.uk
The brain is characterized by a complex and integrated network of interacting cells in which cell-to-cell communication is critical for proper development and function. Initially considered as an immune privileged site, the brain is now regarded as an immune specialized system. Accumulating evidence reveals the presence of immune components in the brain, as well as extensive bidirectional communication that takes place between the nervous and the immune system both under homeostatic and pathological conditions. In recent years the secretion of extracellular membrane vesicles (EMVs) has been described as a new and evolutionary well-conserved mechanism of cell-to-cell communication, with EMVs influencing the microenvironment through the traffic of bioactive molecules that include proteins and nucleic acids, such as DNA, protein coding, and non-coding RNAs. Increasing evidence suggests that EMVs are a promising candidate to study cross-boundary cell-tocell communication pathways. Herein we review the role of EMVs secreted by neural cells in modulating the immune response(s) within the brain under physiological and pathological circumstances.

Keywords: extracellular membrane vesicles, exosomes, immune regulation, central nervous system, neural stem cells, microglia, endothelial cells, brain tumors

\section{INTRODUCTION}

The central nervous system (CNS) is built upon complex cellular networks consisting of neurons - embodying about half the volume of the CNS - and glial cells that make up the rest of the volume and provide support and protection for neurons. CNS cells are structurally in close contact with vascular cells that control their microenvironment through blood flow and the formation of the blood-brain barrier (BBB), whose presence renders the CNS a site that is in principle immunologically distinct. As such, until a few decades ago the brain was generally considered a functionally immune privileged site devoid of immune cells, thus implying its likely "invisibility" to some aspects of immune surveillance (Wilson et al., 2010).

However, since the late 1980s accumulating evidence has been provided that immune cells gain access to (and eventually persist into) the healthy CNS and that immune responses can also be mounted within the CNS (Wekerle et al., 1986). Currently, the brain is more precisely regarded as an immune "specialized" site where a close association between resident CNS cells and, importantly, a bidirectional cell trafficking between the brain and the blood stream is needed primarily for brain integrity and homeostasis, but also for immune functions and repair upon injury (Bradl, 1996). This relevant neuro-immune interplay takes place mainly at the level of the neurovascular unit (NU) that represents a sort of "master checkpoint" of the brain microenvironment. The $\mathrm{NU}$ is the dynamic assembly of endothelial cells within a capillary vessel, the surrounding extracellular matrix (ECM), and a number of accessory cells, including pericytes, capillary-bound astrocytes, perivascular dendritic cells (DCs), macrophages, and neurons (Hawkins and Davis, 2005). On the basis of the evidence to date, it appears that the brain and the immune system have the capacity to establish a very sophisticated biochemical intercourse, which is made of a plethora of paracrine molecules that used to be naively considered solely immune-modulating, while later showing remarkable additional effects on the CNS (Boulanger et al., 2001).

The immune status of the CNS at the level of the NU becomes therefore dichotomous when comparing homeostatic (healthy) to reactive (pathological) conditions.

In the healthy CNS (i) the intact BBB is a gate to the influx of immune cells and macromolecules from the blood stream; (ii) chemokines and cytokines are only produced to a basal level which is not enough to chemoattract immune cells; (iii) CNS endothelial cells have a basal (low) expression of adhesion molecules that are not capable of guiding the migration of immune cells; and (iv) the antigen presentation capacity of brain immune cells is very limited, due to negligible expression of molecules of the major histocompatibility complex (MHC; Carrithers et al., 2000). This situation very rapidly changes under certain pathological conditions in which the brain microenvironment reacts to infections or injuries, or when disease-induced stresses result in secondary effects in the CNS, ultimately leading to neuro-inflammation (Carrithers et al., 2000).

As a consequence of the above, the injured CNS instantly becomes locally immune competent and immune reactive, as suggested by the different organized immune responses that are observed both in and outside the injured area(s). These immune responses can be either tightly adapted against a specific (self vs. 
Table 1 | Extracellular membrane vesicles in the brain.

\begin{tabular}{|c|c|c|c|}
\hline Cell type & Type of EMVs & Function & Reference \\
\hline \multirow[t]{3}{*}{ Microglia } & Shedding vesicles & Non-classical release of IL-1 $\beta$ & Bianco et al. (2005) \\
\hline & Exosomes & $\begin{array}{l}\text { Neuropeptide degradation, glucose catabolism, and } \\
\text { lactate production }\end{array}$ & Potolicchio et al. (2005) \\
\hline & Exosomes & Secretion of insulin-degrading enzyme & Tamboli et al. (2010) \\
\hline \multirow[t]{3}{*}{ Endothelial Cells } & Endothelial microparticles (EMPs) & Cerebrovascular diseases (e.g., stroke) & Simak et al. (2006), Jung et al. (2009) \\
\hline & & $\begin{array}{l}\text { Contribution to MS pathophysiology (enhanced } \\
\text { inflammation and increasing migration), functional } \\
\text { interactions between EMP and leukocytes }\end{array}$ & $\begin{array}{l}\text { Minagar et al. (2001), Jy et al. (2004), } \\
\text { Sheremata et al. (2006) }\end{array}$ \\
\hline & & Contribution to cerebral malaria pathogenesis & $\begin{array}{l}\text { Combes et al. (2005, 2006, 2010), Coltel } \\
\text { et al. (2006) }\end{array}$ \\
\hline \multirow[t]{2}{*}{ NPCs } & Membrane particles & CD133/prominin-1 release & $\begin{array}{l}\text { Marzesco et al. (2005), Huttner et al. } \\
\text { (2008) }\end{array}$ \\
\hline & Exosomes & None & Kang et al. (2008) \\
\hline \multirow[t]{8}{*}{ Brain tumors } & Microvesicles & miRNA and protein transfer; oncogenesis & Skog et al. (2008) \\
\hline & Microvesicles & Tumor progression & Skog et al. (2008), Al-Nedawi et al. (2009) \\
\hline & Exosomes & mtDNA release & Guescini et al. (2010) \\
\hline & Exosomes & Retrotransposon and oncogene transfer & Balaj et al. (2011) \\
\hline & Microvesicles & Angiogenesis & Svensson et al. (2011) \\
\hline & Microvesicles & Transformation & Antonyak et al. (2011) \\
\hline & Microvesicles & None & Graner et al. (2009) \\
\hline & Microvesicles & None & van der Vos et al. (2011) \\
\hline
\end{tabular}

non-self) antigens or involve cellular and molecular pathways specific of innate responses (Griffiths et al., 2007) that involve different types of immune cells (Doring and Yong, 2011; Graeber et al., 2011; Miljkovic et al., 2011) and encompass different cell-to-cell communication programs.

Focusing at cell non-autonomous mechanisms of neuroinflammation in auto/dysimmune inflammatory CNS disorders - multiple sclerosis (MS) being among the most didactical examples - cytokines, chemokines, and other known secreted paracrine factors of intercellular communication are first released by myelin-reactive peripheral $\mathrm{T}$ lymphocytes, then contribute to the bystander activation of other circulating immune cells (e.g., macrophages, neutrophils, and monocytes), and finally are secreted within the CNS also by endothelial cells and neurons/glia alongside the synthesis of classical neurotransmitters (Doring and Yong, 2011; Graeber et al., 2011; Miljkovic et al., 2011). Following these and other mechanisms of information spread, the BBB is disrupted and the CNS acquires signals that allow cells from the hematopoietic system (e.g., T lymphocytes and monocytes) to leave the blood stream and accumulate at the level of the NU. There, they come in contact with local CNS cells, including microglia, leading to a second wave of immune activation, and damage within the CNS (Mae et al., 2011).

While there is general agreement on the ubiquitous and redundant nature of some of the mechanisms regulating the neuroimmune cross talk, still there is very little knowledge of the modalities (as well as the messages) that can be used to convey immune signals into (and around) the CNS (Blalock, 1994).

The recent description of new specialized structures for intercellular communication, such as extracellular membrane vesicles
(EMVs; Cocucci et al., 2009; Thery et al., 2009; Thery, 2011) and tunneling nanotubes (Gerdes and Carvalho, 2008; Gousset et al., 2009), has significantly broadened the range of modalities of intercellular communication. This has led to the challenging hypothesis that some of these extracellular organelles might work as longdistance signaling structures acting into either the extracellular space or biological fluids prior (or as an alternative) establishing direct cell-to-cell contacts between cells in the CNS (Antonucci et al., 2012; Huttner et al., 2012; Saman et al., 2012; Street et al., 2012).

Here we will review the most recent evidence on the role of (secreted) EMVs in regulating the immune response(s) in the brain.

\section{EXTRACELLULAR MEMBRANE VESICLES, EXOSOMES, MICROVESICLES, AND BEYOND}

Cells produce many vesicles regulating the transfer of components between intracellular compartments, but it is now clear that eukaryotic cells also generate membrane vesicles that are secreted into the extracellular space, and are therefore potential carriers for intercellular communication. EMVs are spherical structures that are formed by a lipid bilayer and that contain hydrophilic soluble components. EMVs can form at the plasma membrane (membrane particles) by direct budding or shedding into the extracellular space, giving rise to large-size (>100 nm) membrane particles, also defined as microvesicles, ectosomes, microparticles, or exovesicles (Thery et al., 2009). Alternatively, EMVs can form inside internal (late endocytic) compartments from where they are subsequently secreted by fusion with the plasma membrane. The recycling pathways of endocytosed components from the cell surface involve several sorting events, which are regulated by 
molecular motors and take place at different steps of the pathways (Maxfield and McGraw, 2004). The EMVs generated in multivesicular endosomes (exosomes) are small in size $(40-100 \mathrm{~nm})$. The exact nature of the intracellular compartments from which exosomes derive is still unclear. Recently, another class of microvesicles known as gesicles have been identified (Mangeot et al., 2011). These particles, approximately $100 \mathrm{~nm}$ in diameter and slightly less dense than exosomes, are highly fusogenic and originate from cells that have been induced to overexpress the spike glycoprotein of the vesicular stomatitis virus (VSV-G). Finally, also exosomelike vesicles $(20-50 \mathrm{~nm})$ that express the full-length $55-\mathrm{kDa}$ tumor necrosis factor (TNF) receptor 1 may originate from multivesicular internal compartments (not necessarily being part of the endosomal system), though their nature is not completely clear (Hawari et al., 2004). Irrespective of their origin, all these extracellular vesicles contain cytosol and expose on their outer surface the extracellular side of the membrane from which they are formed (flip-flop mechanism). Large membrane particles and ectosomes have high levels of phosphatidylserine exposed on the outer membrane - usually depending on cell type and stimuli - and express the complement receptor (CR)-1, whereas exosomes are enriched in tetraspanins (e.g., CD63, CD9). EMVs highly enriched in histones are also released by dying and apoptotic cells (Thery et al., 2009).

Despite the lack of definitive evidence for their physiological function in vivo, EMVs appear to constitute a newly recognized means of communication found to be shared by an increasing number of cell types. In 2009 one of the first hypotheses postulating that this sort of mechanism of communication might not only exist, but also be relevant for neural cells, challenged the field (Smalheiser, 2007, 2009). Concomitantly, the capacity to secrete vesicles other than synaptic vesicles has been demonstrated for almost every cell type that constitutes the brain (Von Bartheld and Altick, 2011), namely neurons (Faure et al., 2006; Schiera et al., 2007; Smalheiser, 2007; Putz et al., 2008; Lachenal et al., 2011), astrocytes (Taylor et al., 2007; Guescini et al., 2010), oligodendrocytes (Trajkovic et al., 2008; Hsu et al., 2010; Fitzner et al., 2011), and microglia (Bianco et al., 2005, 2009; Potolicchio et al., 2005; Tamboli et al., 2010). Importantly, EMVs are also secreted by neural stem/precursor cells (Marzesco et al., 2005; Huttner et al., 2008; Kang et al., 2008; Pluchino et al., 2009b). Elevated levels of EMVs expressing the neural stem cell marker prominin-1/CD133 in the cerebrospinal fluid (CSF) are observed in glioblastoma and partial epilepsy, two disease states that are described to be associated to significant changes in adult neurogenesis (Ming and Song, 2011). This suggests the potential value of circulating EMVs as biomarkers of either disease statuses or specific micro-environmental cues in monitoring the behavior of neural progenitors (Huttner et al., 2008, 2012).

Increasing evidence also suggests that EMVs may control fundamental cellular responses, such as intercellular signaling and immune reactions (Simons and Raposo, 2009; Thery et al., 2009). Several types of interactions have been proposed as being mediated by secreted EMVs, mostly based on indirect in vitro evidence. These include the adhesion of EMVs to the recipient cell surface (e.g., through lipids or ligand-receptor interactions; Segura et al., 2007), the internalization of whole EMVs into endocytic compartments (e.g., mediated by receptors; Miyanishi et al., 2007), or the direct fusion of VSV-G expressing gesicles (Mangeot et al., 2011). However, whether EMV fusion occurs on the surface of the recipient cell or after endocytosis via internal compartments (or both) is still unclear. The functional consequences of this sophisticated mode of intercellular communication include the amplification and/or modulation of cellular (e.g., immune) responses (Thery et al., 2009), as well as the acquisition of new functional properties by recipient cells, such as migratory, adhesive, or metastatic abilities (Al-Nedawi et al., 2008).

Extracellular membrane vesicles in the brain have been linked to a number of different processes, such as regulation of myelin membrane biogenesis (Bakhti et al., 2011), transfer of proteins or mRNAs locally in highly polarized structures like neurons (Twiss and Fainzilber, 2009), or trafficking of Nedd4 family interacting protein 1 (Ndfip1) and associated Nedd4 family proteins for the exosomal sequestration of unwanted metal cation-transporting proteins during times of stress (Putz et al., 2008). Besides, EMVs participate in the processing of misfolding/aggregation-prone proteins associated with neurological diseases into their pathological conformations, as well as their subsequent intercellular trafficking (Vella et al., 2008). In particular, exosomes containing $\alpha$-synuclein have been demonstrated to cause cell death in neurons in vitro, thus leading to an amplification and propagation of Parkinson's disease-related pathology, in vitro (Emmanouilidou et al., 2010). In Alzheimer's disease $(\mathrm{AD})$, it has also been reported that $\beta$ cleavage occurs in early endosomes followed by routing of $\beta$-amyloid to multivesicular bodies (MVBs). Subsequently, a minute fraction of $A \beta$ peptides can be secreted from the cells in association with exosomes. Also, exosomal proteins were found to accumulate in the plaques of $\mathrm{AD}$ patient brains, suggesting a role in the pathogenesis (Rajendran et al., 2006; Sharples et al., 2008; Bulloj et al., 2010; Saman et al., 2012).

Moreover, exosomes are involved in the formation/transfer of pathogenic proteins such as prions (Fevrier et al., 2004; Vella et al., 2007; Alais et al., 2008), and may play a role in the spread of hyperphosphorylated tau, the misfolded protein most commonly associated with human neurodegenerative diseases (Goedert et al., 2010).

In addition to proteins, some recent evidence shows that secreted EMVs also contain nucleic acids, including DNA and RNAs, some of which are specifically packaged into EMVs and shuttled to neighboring recipient cells. The RNA has indeed several advantages as an extracellular signaling molecule, and a number of recent reports have envisaged a significant role for both coding and non-coding RNAs carried within EMVs as biologically relevant extracellular signals (Dinger et al., 2008).

Micro RNAs (miRs) are small (21-23 nt) non-coding RNAs that post-transcriptionally regulate gene expression by translational inhibition or destabilization of mRNAs (Bartel, 2009). As such, a specific miR transferred within EMVs may simultaneously regulate multiple target genes, thereby enabling complex changes in multiple protein expression profiles. Recently, miRs have been found in the extracellular space and fluids such as blood plasma, urine, saliva, and sperm. Extracellular miR profiles have been considered as putative biomarkers of pathological states (De Smaele et al., 2010; Ciesla et al., 2011), and the relatively high stability of the 
cell-free, circulatory miRs has been attributed to their associations with RNA-binding proteins or their encapsulation within vesicles (Hunter et al., 2008; Wang et al., 2010; Chen et al., 2012). Intriguingly, a reminiscence of this evidence dates back to 1977 when small particles possessing the characteristic of polysomal tumor virus-specific RNA were first detected in the CSF of patients with various types of CNS solid tumors (Cuatico et al., 1977). The miR profiles of tumor-secreted exosomes commonly mirror those of the parent cells (Taylor and Gercel-Taylor, 2008; Rabinowits et al., 2009), while viral nucleic acids may hijack the host's exosomes to affect immune regulation in recipient cells (Gourzones et al., 2010; Meckes et al., 2010; Pegtel et al., 2010).

More recent perspectives have expanded beyond the role of extracellular miRs as passively released indicators of disease. Indeed, the extracellular secretion of miRs has been found to be both active and energy-dependent, with sorting of specific miRs into EMVs occurring prior to release (Gibbings et al., 2009; Kosaka et al., 2010; Zhang et al., 2010). Some of these studies have in fact highlighted the fact that some of the identified RNAs [e.g., over 120 mature miRs within exosomes from mast cells and recently also pre-miRs in EMVs from mesenchymal stem cell (MSC)] are expressed at higher levels or even uniquely within EMVs, as compared to donor cells (Valadi et al., 2007; Chen et al., 2010). Moreover EMVs derived from MSC not only contain pre-miRs but also Ago2, a component of the machinery for their maturation, as well as mature, functional miR (Collino et al., 2010). This would suggest the existence of dedicated (and still not clarified) cellular trafficking control mechanisms for recycling, collecting, and packaging specific nucleic acids into EMVs.

\section{EXTRACELLULAR VESICLES AS CONVEYORS OF IMMUNE RESPONSES}

Recently, several studies have focused on the role of EMVs as conveyors of immune response (Clayton and Mason, 2009; Anand, 2010; Bobrie et al., 2011; Chaput and Thery, 2011). The impact of EMV-mediated immune modulation remains an on-going controversy, with the net functional effect - that is promotion or suppression of the immune response-being very much dependent on the nature of the parent cell (Thery et al., 2009).

Exosomes secreted by antigen presenting cells (APCs), such as DCs and B lymphocytes, carry a range of immune-stimulatory molecules including MHC-I, MHC-II, as well as co-stimulatory molecules such as CD80/B7.1 and CD86/B7.2. DC exosomes activate $\mathrm{T}$ cells, and participate to the development of antigen-specific immune responses (Raposo et al., 1996; Zitvogel et al., 1998; Thery et al., 1999; Clayton et al., 2001; Segura et al., 2005a,b; Bhatnagar et al., 2007).

Similarly, exosomes derived from B lymphocytes are enriched in proteins that facilitate antigen presentation and can stimulate $\mathrm{T}$ cells in vitro, implying a role in the maintenance of $\mathrm{T}$ cell memory or T cell tolerance (Raposo et al., 1996; Escola et al., 1998; Muntasell et al., 2007). Furthermore, B cell-derived exosomes have been found to be specifically delivered to follicular DCs (FDCs) in vitro, thus suggesting a potential route by which FDCs might passively acquire peptide-loaded MHC class II molecules for further stimulation of $\mathrm{CD}^{+}{ }^{+} \mathrm{T}$ cells (Denzer et al., 2000). Preclinical studies have also demonstrated that antigens increase their immunogenicity when trafficked by exosomes (Chaput and Thery, 2011).

While it is firmly established that miRs play an important role in immune regulation (O'Connell et al., 2010), only recently has evidence been presented supporting the exosomal transfer as a route by which miRs can affect such activity. Mittelbrunn et al. (2011) have demonstrated in vitro an antigen-driven, immune synapse (IS)-dependent, unidirectional transfer of exosomes between $\mathrm{T}$ cells and APCs. Antigen-induced IS formation was found to result in a polarization of exosome-generating MVBs toward the IS and a concomitant enhancement in exosome secretion. Furthermore, J77 T cells transduced to overexpress miR-335 were observed to knockdown the miR-335 target gene Sox 4 in recipient Raji B cells in an antigen-specific manner correlating with the transfer of the exosomal marker CD63. Inhibition of IS and exosome formation were found to impair T cell to APC exosome and miR transfer, respectively. While not directly affirming the role of exosomal miR delivery in immune regulation, these results do imply the feasibility of such a mechanism (Mittelbrunn et al., 2011). Nevertheless, the ultimate contribution of exosomes to immune regulation, and particularly the role of miRs in this process, remains controversial due to the inherent complexities of the immune response mechanism.

Given that almost all cell types secrete EMVs it should be taken into account that, in contrast to the in vitro conditions in which often only one cell type is analyzed, the in vivo interplay is much more complex and the vesicle exchange may very likely be bidirectional. The mechanism of vesicle transfer (as well as the signals conveyed with vesicles) might also be different between various cell types, thus leading to cell- or context-specific vesicle effects (Koppler et al., 2006). When trying to translate the immune properties of a certain subset of vesicles, the perspective from which the system is evaluated should be carefully taken into account (Brown et al., 2008). As such, depending on the donor cell type, EMVs either activate or suppress the immune response (Valenti et al., 2006, 2007; Wieckowski and Whiteside, 2006; Zhuang et al., 2011). While the delivery of exogenous miRs to target cells appears to be facilitated by a vesicle-mediated specificity, a firm understanding of the recipient uptake mechanisms remains elusive (Chen et al., 2012).

In the brain, the regulation of immune functions by EMVs has been convincingly reported for microglia/macrophages, endothelial cells, and brain tumor cells, while only indirectly ascribed to stem cells, so far (Table 1).

\section{EXTRACELLULAR VESICLES AND MICROGLIA/MACROPHAGES}

Microglia, the resident macrophages of CNS parenchyma, and macrophages, are two related classes of cells (Raivich and Banati, 2004) that are now recognized as the prime components of the intrinsic brain immune response, alternatively defined as the vanguard in host defense and tissue repair (Streit and Kincaid-Colton, 1995; Rock and Peterson, 2006).

Historically, the function of microglia has been somewhat controversial. This is in part due to the extremely plastic phenotype and broad activity of this cell type (Graeber, 2010). However, our understanding of the role of microglia is now evolving. In addition to their well-established housekeeping properties (Kettenmann et al., 2011; Tremblay et al., 2011), microglia are increasingly being 
attributed the function of coordinators of the trafficking of other immune cells into the nervous system (Aloisi et al., 2001). The current concept of microglia is as dynamic sensors of brain trauma, disease, and degeneration (Kettenmann, 2007), yet there is a general agreement that they exhibit both a bright and a dark side in this role.

Microglia function in normal brain physiology is still poorly defined, but resident non-activated microglial cells act as poor APCs due to their constitutive low levels of MHC-I/II molecules. However, upon activation they rapidly express MHC-I/II proteins and quickly become efficient "non-professional" antigen presenters. The non-professional nature and CNS-localization of microglia result in a notably different antigen presentation mechanism than that generally established for DCs. Upon internalizing antigens, DCs exit the tissue in which they reside (typically thought to be restricted to the spleen, lymph nodes, the skin, and mucosal surfaces) and enter the draining lymph nodes where they stimulate naïve T cells (Ransohoff and Cardona, 2010). In contrast, microglia encounter $\mathrm{T}$ cells during inflammation when $\mathrm{T}$ cells cross the BBB thanks to specialized surface antigens and then directly bind to microglia in order to receive antigens. Once they have been presented with antigens, $T$ cells fulfill a variety of effector functions including pro-inflammatory recruitment, formation of immunological memories, and secretion of cytotoxic molecules (Yang et al., 2010).

Microglial cells secrete EMVs, and proteomic studies have identified several microglial vesicle proteins that were already reported in EMVs from B cells and DCs (Potolicchio et al., 2005). Microglial EMVs (mirroring their parent cells) also express MHC class II molecules, the levels of which are up regulated in response to stimulation with interferon (IFN) $-\gamma$ (Potolicchio et al., 2005). The release of EMVs from microglial cells is also enhanced in critical conditions where immune activation is required. Upon activation, microglia release both soluble pro-inflammatory cytokines, such as interleukin (IL)-1 $\beta$, IL- 6 , and TNF- $\alpha$, as well as shed membrane vesicles (Bianco et al., 2009). Activated microglial cells also rapidly release IL- $1 \beta$ by a non-classical pathway of secretion leading to vesicle shedding (MacKenzie et al., 2001; Bianco et al., 2005) (Table 1).

There is also evidence of increased number of microgliaderived EMVs secreted by microglial cells into the CSF circulation in rodents with CNS inflammation, thus suggesting that circulating EMVs can be considered as surrogate markers of local (compartmentalized) vs. systemic inflammation ultimately affecting the CNS (Antonucci et al., 2012).

\section{EXTRACELLULAR VESICLES AND ENDOTHELIAL CELLS}

Endothelial cells release small membrane vesicles, known as endothelial microparticles (EMPs), that have been regarded as useful indicators of the functional state of the diseased endothelium; they may also potentially play key roles in the disease pathogenesis (Chironi et al., 2009; Morel et al., 2011). EMPs are found in the circulation of healthy subjects but their numbers increase in various pathological conditions such as thrombotic or infectious diseases, suggesting that these vesicles can act as pro-inflammatory and pro-coagulant regulators (Rabelink et al., 2010; Morel et al., 2011). EMPs released from the injured endothelium after cerebrovascular diseases such as cerebral stroke are found associated with microcirculatory injury, capillary blocking, acute and chronic inflammatory processes, and disruption of the BBB. The level of circulating EMPs has also been correlated with stroke severity, brain lesion volume, and outcome (Simak et al., 2006; Jung et al., 2009).

During CNS inflammation, the increased permeability of the BBB largely results from interactions among activated monocytes and $\mathrm{T}$ cells with cerebral endothelial cells, which - coupled with lymphokine and chemokine production - leads to cell adhesion to the cerebrovascular endothelium and trans-endothelial migration across the BBB. Upon activation by inflammatory cytokines such as IFN- $\gamma$ and TNF- $\alpha$, endothelial cells secrete EMPs. This has been reported on MS studies in which a correlation between plasma CD $31^{+}$EMP levels and clinical exacerbations, as well as brain magnetic resonance imaging (MRI) disease activity, has been reported (Minagar et al., 2001). Interestingly, the plasma levels of $\mathrm{CD} 31^{+}$EMP decrease upon disease modifying drug therapy with IFN- $\beta 1$ la (Sheremata et al., 2006) and this decrease correlates well with decrease in the number and volume of contrast enhancing T1-weighed lesions in MRIs (Lowery-Nordberg et al., 2011).

The role of EMPs in the pathogenesis of MS has been further explored and functional interactions between EMP and leukocytes have been assessed in vitro. These studies revealed that EMPs are captured preferentially by monocytes, less so by neutrophils, and have little affinity for lymphocytes (Jy et al., 2004). Bound EMPs activated monocytes leading to an increased expression of CD11b and migration through the cerebral endothelial cell layer. In an in vitro model for trans-endothelial migration, EMP-monocyte complexes showed a higher rate of migration of monocytes through monolayers of human cerebral microvascular endothelial cells (ECs) vs. monocytes alone.

Endothelial microparticles may then contribute to MS pathophysiology, enhancing inflammation, and increasing transendothelial migration of monocytes by binding to and activating monocytes, likely through CD54 (Jy et al., 2004).

Circulating EMPs are also increased in patients with severe cerebral malaria (CM; Coltel et al., 2006; Combes et al., 2006, 2010), the major fatal complication of plasmodium infection, where they appear to have a pathogenic role. This is strongly supported by the finding that ABCA1 transporter deletion associated with an impaired EMP production confers a complete protection against CM (Combes et al., 2005).

Hergenreider et al. have recently investigated a putative role for EMPs in mediating the atheroprotective properties of the parent cell. The shear-responsive transcription factor Krüppel-like factor 2 (KLF2), was recently found to up-regulate the miR-143/145 cluster in KLF2-transduced (or simply shear-stress-stimulated) ECs. Given the role of miR-143/145 in controlling the phenotype of smooth muscle cells (SMCs), Hergenreider et al. have proposed a miR-143/145-based - EMV-mediated - communication between parent ECs and SMCs. Real-time PCR analysis of EMVs isolated from KLF2-activated ECs showed enrichment in miR-143/145. In vitro EC-to-SMC transfer of miR-143/145 via EMVs was evidenced in co-cultures by restoration of SMC miR$143 / 145$ content to levels near those measured pre-knockdown and a concomitant knockdown of mRNAs known to be targeted by the miR-143/145 cluster (e.g., ELK1, KLF4, CAMK2d, and SSH2). In vivo, the delivery of isolated atheroprotective EC EMVs into 
atherosclerosis-prone $\left(\mathrm{ApoE}^{-l-}\right)$ mice resulted in a reduction of aortic atherosclerotic lesion formation (Hergenreider et al., 2012) (Table 1).

\section{EXTRACELLULAR VESICLES AND BRAIN TUMORS}

The literature describes contradictory functions in immune responses of vesicles secreted by tumor cells in vitro: on one hand transferring antigens to DCs to allow cross-presentation (Wolfers et al., 2001), and subsequent stimulation of cytotoxic lymphocytes (Zitvogel et al., 1998; Gastpar et al., 2005); on the other inhibiting several players of the effector step of anti-tumor immune responses that include the inhibition of natural killer (NK) cell proliferation and cytolytic function (Liu et al., 2006; Clayton et al., 2007).

In this context the glioma model system (gliomas are classified according to the cells that give rise to the tumor, e.g., astrocytoma, oligodendroglioma, glioblastoma (GBM), and oligo/astrocytoma) has been extensively examined for vesicle release and function (Trams et al., 1981; Skog et al., 2008; Al-Nedawi et al., 2009; Graner et al., 2009; Guescini et al., 2010; Balaj et al., 2011; Graner, 2011; Svensson et al., 2011; van der Vos et al., 2011).

The original idea was that tumor-derived EMVs would behave like cancer vaccines because of the presence of tumor-specific antigens and heat shock proteins known to favor APC activation. Evidence of induction of anti-tumor immune responses in vivo (Graner et al., 2009) involving both specific $\mathrm{CD}^{+}$cytotoxic Tlymphocyte (CTL) response against autologous tumor cells (Bu et al., 2011) and an effective antibody production (Graner et al., 2009) have been reported.

A significant proportion of human gliomas express a truncated, constitutively active mutant of the epidermal growth factor receptor (EGFR) known as EGFR variant III (EGFRvIII). EGFRvIII expression is specific to some tumors and defines clinically distinct glioblastoma subtypes (Pelloski et al., 2007). Thus, a patient's EGFRvIII status (positive or negative) determined by analysis of EMVs carried in the serum can be diagnostic of their tumor type. EGFRvIII mRNA is found in EMVs from many patients tested, but in none of the controls. This finding might have diagnostic implications for EMV as a biomarker (Skog et al., 2008).

Recently it has been demonstrated that EMVs shed by glioma cells promote oncogenic transformation of neighboring cells thought the transfer of the above described EGFRvIII (Al-Nedawi et al., 2008) as well as the protein cross-linking enzyme tissue transglutaminase (tTG) that conferred certain characteristics of cancer cells (e.g., anchorage-independent growth and enhanced survival capability) to non-transformed fibroblasts and epithelial cells (Antonyak et al., 2011).

Much of the current knowledge regarding the immunology of tumor-derived EMVs is dominated by the opinion that such vesicles mediate immune suppression by increasing the activity of regulatory $\mathrm{T}$ cells (Treg) and myeloid-derived suppressor cells, suppressing activated $\mathrm{T}$ cells and NK cells, and by inhibiting DC maturation (Iero et al., 2008). In the same population of vesicles therefore seems to be a range of immune-stimulatory and potentially immune-suppressive functions. To date, these findings have been robustly demonstrated for EMVs released by tumor types other than brain tumors, but initial evidence of immune suppression has also been reported for GBM, thus correlating with the abnormal cellular immune response observed in patients.

In particular, peripheral blood mononuclear cells from healthy donors exposed in vitro to GBM exosomes displayed a suppressed phenotype with higher CD14 expression and lower HLA-DR (vs. non-exposed cells; de Vrij et al., 2011). Moreover, exosomes isolated from U87 and U138 human glioblastoma cell lines significantly inhibited the proliferation of $\mathrm{T}$ cells in vitro an effect likely resulting from FasL expression by tumor cells inducing apoptosis of activated T cells (de Vrij et al., 2011; Sabin et al., 2011).

The stem cell theory of carcinogenesis (Trosko and Chang, 1989) might suggest that a common cell signaling system operates in normal and malignant neural stem cells (Gilbertson and Rich, 2007). It has been in fact suggested that intrinsic brain tumors originate from a population of neural stem/precursor cells (NPCs) within prototypical germinal niches of the post-natal brain, including the sub-ventricular zone of the lateral ventricles (Hemmati et al., 2003; Singh et al., 2004; Uchida et al., 2004; Vescovi et al., 2006). NPCs, as self-renewing precursors capable of producing progeny along neuronal or glial lineages, commonly possess features associated with CNS tumors, including a robust proliferative potential and a diversified progeny (Nguyen et al., 2012). Cancer stem cells also express the stem cell marker prominin/CD133 (Nguyen et al., 2012). Brain tumor cells are described as "abnormal deranged cells" of the CNS and may recapitulate many features, albeit exaggerated, of normal cells, thus in turn helping in the understanding of normal cell biology and cell differentiation (Sanai et al., 2005; Jacques et al., 2010) (Table 1).

It is therefore plausible that the similarities between normal stem cells and cancer stem cells could extend to the unique relationship that stem cells have with their immediate microenvironments.

\section{EXTRACELLULAR VESICLES AND STEM CELLS}

Stem cells are the leading candidates as a source for transplantation in patients with neurological diseases. A variety of stem cells - including hematopoietic stem cells, MSCs and NPCs - display the potential to promote immune regulation, thus giving rise to the speculation that these properties are likely due to a common functional signature that in turn widens the possible source for cell therapy (Uccelli et al., 2008; Martino et al., 2011). Many studies focusing at the understanding of the possible crosstalk between NPCs and immune cells have been conducted, based on the observation that mouse and human NPCs share the expression of an array of functional immune-like receptors (e.g., cell adhesion molecules and pro-inflammatory chemokine receptors; Butovsky et al., 2006). The immune regulatory actions of transplanted NPCs have been described in different experimental models of neurological diseases, such as acute and chronic experimental autoimmune encephalomyelitis (EAE), spinal cord injury (SCI), stroke, and neurometabolic diseases. In all these models transplanted cells improved the clinical outcome mostly by immune modulation, neurotrophic, and neuroprotective effects, rather than substantial replacement of endogenous cells.

This has been generally attributed to an in vivo NPC capability to modulate the infiltration of blood-borne encephalitogenic $\mathrm{T}$ cells at the level of the CNS, through (i) the down-regulation 
of intercellular adhesion molecule (ICAM)-1 and leukocyte function associated (LFA)-1, two cell adhesion molecules involved in $\mathrm{T}$ cell migration, at the level of the BBB; (ii) the induction of $\mathrm{T}$ cell-specific apoptosis or; (iii) the increase of the number of regulatory T cells (Einstein et al., 2003; Pluchino et al., 2005). The very same findings are consistent with in vitro observations documenting the capacity of NPCs to inhibit both non-antigen-specific as well as antigen-specific $\mathrm{T}$ cell activation and proliferation (Einstein et al., 2003; Fainstein et al., 2008), and apoptosis induction via a FasL-dependent mechanism (Knight et al., 2010). The suppression of $\mathrm{T}$ cell proliferation has been attributed at least in part to the production of soluble mediators, such as nitric oxide (NO) and prostaglandin E2 (PGE2; Wang et al., 2009). An enhanced efficacy has been obtained with genetically engineered NPCs expressing IL10, an anti-inflammatory cytokine that efficiently suppresses EAE (Croxford et al., 2001), as compared to control (non-engineered) NPCs (Yang et al., 2009). Similar results to those achieved in rodent EAE have been obtained in non-human primates with human NPCs (Kim et al., 2009a; Pluchino et al., 2009a). Further work on rodent models of stroke documented that, thanks to their reactivity to CCL2/CCR2 and CXCL12/CXCR4 axes, NPCs migrate in the perilesional area and persist there in an undifferentiated phenotype (Imitola et al., 2004; Darsalia et al., 2007; Bacigaluppi et al., 2009; Sun et al., 2010; Andres et al., 2011). Transplanted NPCs, engaged in a complex interplay with the inflammatory environment, are able to reduce the number of infiltrating cells (neutrophils) in the brain as well as the numbers of activated macrophages in lymphoid organs (Lee et al., 2008). NPCs also vary the bioavailability of immune mediators (Kilic et al., 2008), i.e., increasing gene expression levels of vascular-endothelial growth factor (VEGF) and down-regulating in the ischemic region multiple RNA species involved in inflammation, including IFN$\gamma$, TNF- $\alpha$, IL-1 $\beta$, IL-6, and leptin receptor (Bacigaluppi et al., 2009). In models of stroke, NPCs demonstrated the ability to modify the ischemic environment via induction of neurotrophic factors [such as stromal-derived factor (SDF)-1/CXCL12, insulinlike growth factor (IGF)-1, VEGF, transforming growth factor (TGF)- $\beta$, and brain-derived growth factor (BDNF)] and activation of selected aspects of the inflammatory response, particularly $\mathrm{CD}_{11 \mathrm{~b}}{ }^{+}$microglia/macrophages (Capone et al., 2007).

Several studies have also highlighted the crucial role of the interaction between transplanted NPCs and microglia/macrophages, although with controversial results. On one side there is the idea that microglia activation might be required for transplanted NPCs to exert their neuroprotective action, given the indirect evidence of its increased number after NPC-transplantation in models of stroke (Capone et al., 2007; Daadi et al., 2010). This is also more directly suggested by the increased ischemic volume in mice affected by experimental middle cerebral artery occlusion (MCAo) after selective ablation of $\mathrm{CD}_{11} \mathrm{~b}^{+}$microglia in CD11b-thymidine kinase mutant-30 mice (Lalancette-Hebert et al., 2007). On the other hand, significant reduction of microglia/macrophages is observed after the intravenous NPC-transplantation in wild type MCAo mice that leads to increased neuronal survival and recovery of locomotor functions (Lee et al., 2008; Bacigaluppi et al., 2009).

In experimental SCI, NPCs injected into the CSF synergize with myelin-specific $\mathrm{T}$ cells used as a vaccination therapy that stimulated transplanted NPCs to specifically migrate to the site of injury, while also instructing the local macrophages/microglial cells toward a tissue-protective phenotype (Ziv et al., 2006). Recently, NPCs that were implanted focally at the level of the severely contused mouse spinal cord, survived at the boundaries of the injured spinal cord, always in very close contiguity with blood vessels, while retaining undifferentiated morphology and ultrastructure and intimately interacting with phagocytic cells and astrocytes via cellular junctional coupling. This was associated to increased levels of inflammatory mRNAs and significant reduction of the proportion of "classically activated" (M1) infiltrating macrophages and, in turn, remarkable promotion of the healing of the injured cord (Cusimano et al., 2012).

Immune regulation mediated by transplanted NPCs may take place in the CNS (Pluchino et al., 2005), as well as in secondary lymphoid organs such as the lymph nodes or the spleen (Einstein et al., 2007; Pluchino et al., 2009b). Einstein et al. have shown that in the production of pro-inflammatory cytokines in response to myelin oligodendrocyte glycoprotein (MOG) 33-35 peptide EAE-derived lymph node cells were strongly inhibited by NPCs. Furthermore, primed T cells from mice treated with NPCs were also deficient in their ability to adoptively transfer EAE to a naïve host (Einstein et al., 2007). We have shown striking peripheral (i.e., at the level of the secondary lymphoid organs) accumulation, survival, and long-term persistence of NPCs injected sub-cutaneously into mice with EAE. In this experimental context, NPCs showed negligible propensity to accumulate into the brain, but rather were consistently capable of modifying the perivascular lymph node microenvironment by hindering the activation of myeloid DCs via a bone morphogenetic protein (BMP)-4 dependent mechanism, which in turn limited the expansion of antigen-specific encephalitogenic T cells at the sites of antigen presentation (Pluchino et al., 2009b). The survival of NPCs outside the CNS was likely promoted by the in situ increased levels of major stem cell-fate determinants, including the BMP-4 and -7, sonic hedgehog (Shh), and the BMP antagonist Noggin, which were released both by transplanted NPCs and immune cells (Pluchino et al., 2009b). Also human NPCs have been shown to interfere with a number of major DC functions, such as the differentiation of myeloid precursor cells (MPCs) into immature DCs (iDCs), and the maturation of iDCs into functional (antigen presenting) mature DCs. (Pluchino et al., 2009a).

The general consensus from these and other studies is now that transplanted non-hematopoietic stem cells promote remarkable clinical and pathological amelioration from inflammatory-driven CNS damage and that this is due to mechanisms alternative to the initially expected cell replacement (Martino and Pluchino, 2006).

It is therefore possible to speculate that in addition to paracrine and endocrine factors that transplanted stem cells will undoubtedly release at the level of the extracellular space, EMVs are also likely to play a role in the mediation of some of the parental cell's functions in shaping the host microenvironment.

One of the first reports on stem cell-derived EMVs identified two classes of membrane particles (named P2 and P4 by the authors), with diameters of 600 and $50-80 \mathrm{~nm}$, respectively, which carry the stem cell marker prominin-1/CD133, a pentaspan 
membrane protein found on the membrane protrusions of the apical surface of neuroepithelial cells, in the lumen of the neural tube in the developing embryonic mouse brain. The P2 and P4 classes of particles were observed in the ventricular fluid during the onset and early stages of neurogenesis, respectively, and their presence correlated with a change in the nature of the neuroepithelial membrane protrusions. It has been hypothesized that these particles may exert a signaling role or they may be a mean of discharging membrane microdomains that endow these cells with stem/progenitor cell properties contributing to their differentiation (Marzesco et al., 2005).

Embryonic stem (ES) cells have also been shown to be a rich source of EMVs. Mouse and human ES cell-EMVs traffic various stem cell-specific molecules that regulate self-renewal of pluripotent cells in embryoid bodies and may affect the growth of recipient cells, e.g., contributing to cell-fate decision.

Embryonic stem cell-EMVs are in fact highly enriched in Wnt3 protein and mRNAs for transcription factors such as Oct-4, Nanog, and Rex-1, which are markers of pluripotency that are typically implicated in self-renewal. Furthermore, they are capable of reprogramming hematopoietic progenitors cells (HPCs) not only by stimulating them with surface-expressed ligands but also by delivering ES-derived Oct-4 mRNA which is subsequently translated into Oct- 4 protein within the recipient cell (Ratajczak et al., 2006).

Recently, ES cell-EMVs have been demonstrated to be capable of transferring a subset of miRs to mouse embryonic fibroblasts (MEFs); the most efficiently transferred miRs (as determined by real-time quantitative RT-PCR analysis of the recipient cells) were those abundant in the parent ES cells but relatively deficient in recipient fibroblasts (i.e., miR-290, miR-291-3p, miR-292-3p, miR294 , and miR-295), suggesting a tightly regulated transfer process (Yuan et al., 2009).

It has been also recently proposed that the interaction of stem cells with the microenvironment has a critical role in defining stem cell phenotype. This concept acquires relevance especially in the context of tissue/cellular injury, as the continuous genetic modulation through EMV transfer between neighboring cells can be a key determinant of stem cell phenotype variation (Quesenberry and Aliotta, 2008; Aliotta et al., 2010). This hypothesis was first proposed for marrow cells and their capacity to assume the phenotype of other hematopoietic cells or non-hematopoietic cells (conversion). The "continuum model" of stem cell regulation states that the potential of marrow stem cells continually changes with cell cycle transit and that marrow stem cell are indeed cycling cells (Quesenberry and Aliotta, 2008; Aliotta et al., 2010). Studies with mouse lung-derived EMVs and mouse bone marrow cells have shown that the capacity to take up EMVs varies with cycle phase. Thus, phenotype modulation at the stem cell level involves both cell cycle and EMV phenotype change (Quesenberry and Aliotta, 2008).

Extracellular membrane vesicles derived from human liver stem cells (HLSC) induce proliferation and apoptosis resistance in cultured human hepatocytes and favor liver regeneration in hepatectomized rats through the transfer of a defined pattern of mRNAs associated with cell functions related to the control of transcription (e.g., DMRT2, HOXC12, NFIX, and HOXA3), translation (AGO2), and proliferation (e.g., MATK, MRE11A, CHECK2, and CDK2; Herrera et al., 2010).

Interestingly, the pattern of genes present in HLSC-derived EMVs is substantially different from that of EPCs and MSCs (Deregibus et al., 2007; Bruno et al., 2009) indicating a parental cell-specific signature.

Exosomes from human ES cell-derived MSCs have been recently shown to reduce infarct size in a mouse model of myocardial ischemia/reperfusion injury and in this setting exosomes have been identified as the cardioprotective component in the MSC paracrine secretion (Lai et al., 2010). These very same MSC-derived exosomes contained the hsa-let-7b and hsa-let-7g predominantly in the precursor form (Chen et al., 2010).

Systemically injected EMVs from human bone marrow-derived MSCs have been shown to accelerate kidney repair in a mouse model of acute kidney injury (AKI) by inhibiting apoptosis and stimulating tubular epithelial cell proliferation. EMVs also significantly reduced the impairment of renal function. Pretreatment of EMVs with RNase to inactivate their RNA cargo abrogated these protective effects. Moreover, EMVs capable of reducing the acute injury also protected from later chronic kidney disease (Gatti et al., 2011).

All these studies suggest the existence of a bidirectional exchange of genetic information between stem and neighboring cells, or reciprocally from injured cells to bone marrow-derived or resident stem cells that in turn lead to tissue repair (Camussi et al., 2010). In this context, embryonic and adult stem cell-derived EMVs shuttle defined patterns of mRNAs and miRs that are internalized by a receptor-mediated mechanism in target cells, and may induce de-differentiation of cells surviving injury with cell cycle re-entry and tissue self-repair; conversely, it might be envisaged that transcripts delivered by EMVs from injured cells may reprogram the phenotype of stem cells to acquire specific features of the inflamed/damaged microenvironment.

The first tentative evidence of immune modulation by NPCderived exosomes emerged from experiments in which the culture supernatant of hNPC (HB1.F3) suppressed the activation and proliferation of human $\mathrm{T}$ cells by apoptosis and cell cycle arrest. Exosomes isolated from hNPCs and added to the supernatant of cultured $\mathrm{T}$ cells resulted in a similar suppression by G0/G1 cell cycle arrest. This reinforces the possibility that (at least part of) the immune modulatory effects of hNPCs might be mediated by secreted EMVs/exosomes (Kim et al., 2009b).

The hypothesis of EMV secretion by NPCs introduces a completely different dimension to the therapeutic applications of NPCs in regenerative medicine. By replacing transplantation of NPCs with administration of their secreted products (including EMVs), many of the limitations and safety concerns associated with the transplantation of viable replicating cells, such as tumors arising from transplanted NPCs, could be mitigated (Amariglio et al., 2009).

As naturally occurring "nanoparticles," EMVs may benefit from the expression of specific membrane molecules that might confer them a potential mechanism for the homing to a specific tissue or microenvironment.

The future challenge is the discovery of the molecules (i.e., proteins, mRNAs, or miRs) that might recapitulate the therapeutic 
efficacy of transplanted NPCs, the engineering or modification of the exosome surface antigen and internal content, and their in vivo delivery to the target site.

Very recent studies report on the use of exosomes as a fast and selective brain-targeted delivery system of therapeutic molecules able to overcome the major hurdle imposed by the BBB. Systemically injected immature DC-derived exosomes, engineered to express Lamp2b fused to the CNS-specific rabies viral glycoprotein (RVG) peptide, have been shown to deliver GAPDH short interfering RNA (siRNA) to the mouse brain (Alvarez-Erviti et al., 2011). The siRNA was efficiently delivered to neurons, microglia, oligodendrocytes, and oligodendrocyte precursors. The same report details similar achievements with siRNA that interfere with the enzyme $\beta$-secretase 1 (BACE-1), a foremost target for the treatment of $\mathrm{AD}$, where the amyloid- $\beta(\mathrm{A} \beta)$ peptide is believed to play a key role in the pathogenesis of $\mathrm{AD}$ (Alvarez-Erviti et al., 2011).

Zhuang et al. have recently explored the use of $\mathrm{T}$ cellderived exosomes to deliver anti-inflammatory drugs to the mouse brain through a non-invasive intranasal route. The authors challenged three different models of brain inflammation that included lipopolysaccharide (LPS)-induced inflammation, MOG-induced EAE and the orthotopic glioblastoma (GL26) model. Intranasally administered exosome-encapsulated antiinflammatory drugs (curcumin or the signal transducer and activator of transcription 3 (Stat3) inhibitor JSI124) were selectively taken up by microglia, both "resting" and "activated." The administration of exo-curcumin led to a significant reduction in the number of microglial cells, while exo-JSI124 resulted in the enhancement of tumor apoptosis and a concomitant reduction in disease progression in all the tested models. The immune reaction toward the parental cell exosomal antigens, in terms of immune tolerance or immune responsiveness, needs further evaluation. The authors speculate that exosomes taken up by naïve microglial cells may lead to the induction of an immune tolerance to antigens released from the cells producing the exosomes,

\section{REFERENCES}

Alais, S., Simoes, S., Baas, D., Lehmann, S., Raposo, G., Darlix, J. L., and Leblanc, P. (2008). Mouse neuroblastoma cells release prion infectivity associated with exosomal vesicles. Biol. Cell 100, 603-615.

Aliotta, J. M., Pereira, M., Johnson, K. W., De Paz, N., Dooner, M. S., Puente, N., Ayala, C., Brilliant, K., Berz, D., Lee, D., Ramratnam, B., Mcmillan, P. N., Hixson, D. C., Josic, D., and Quesenberry, P. J. (2010). Microvesicle entry into marrow cells mediates tissue-specific changes in mRNA by direct delivery of mRNA and induction of transcription. Exp. Hematol. 38, 233-245.

Al-Nedawi, K., Meehan, B., Micallef, J., Lhotak, V., May, L., Guha, A., and Rak, J. (2008). Intercellular transfer of the oncogenic receptor EGFRvIII by microvesicles derived

whereas the exosomes taken up by activated microglial cells may lead to activation of immune cells (Zhuang et al., 2011) (Table 1).

The feasibility of scaling up production and purification of clinical grade exosomes using a Good Laboratory Practice process using DC-derived exosomes has been partially addressed (Escudier et al., 2005), and various clinical trials are about to start (Chaput and Thery, 2011).

\section{CONCLUSION}

Depending on their origin, EMVs are able to either stimulate or repress functions of the immune system and drive regenerative processes. Vesicles secreted by stem cell sources other than NPCs have begun to prove that vesicles are endowed with immune modulatory properties that might make them promising agents to be exploited for therapeutic purposes.

The future challenge for exosomal research is to continue looking into innate (physiological) mechanisms with the focus of translating the knowledge of basal (vs. reactive) cell functions into innovative highly clinical impact therapeutics.

\section{ACKNOWLEDGMENTS}

This work has received support from the National Multiple Sclerosis Society (NMSS, partial grants RG-4001-A1 to Stefano Pluchino), the Italian Multiple Sclerosis Association (AISM, grant 2010/R/31 to Stefano Pluchino and 2010/R/31/B to Chiara Cossetti), the Italian Ministry of Health (GR08-7 to Stefano Pluchino), Wings for Life (grant XBAG/165 to Stefano Pluchino), Banca Agricola Popolare di Ragusa (BAPR, unrestricted grant to Stefano Pluchino), and the European Research Council (ERC) under the ERC-2010-StG Grant agreement no 260511-SEM_SEM (to Stefano Pluchino). Chiara Cossetti has received a fellowship (SFRH/BD/15899/2005) from the Fundação para a Ciência e a Tecnologia (FCT) and is now the recipient of the FISM fellowship 2010/R/31/B. Nunzio Iraci is the recipient of a Long-Term Fellowship (code: FYE) from the Federation of European Biochemical Society (FEBS).

and Rechavi, G. (2009). Donorderived brain tumor following neural stem cell transplantation in an ataxia telangiectasia patient. PLoS Med. 6, e1000029. doi:10.1371/journal.pmed.1000029

Anand, P. K. (2010). Exosomal membrane molecules are potent immune response modulators. Commun. Integr. Biol. 3, 405-408.

Andres, R. H., Choi, R., Pendharkar, A. V., Gaeta, X., Wang, N., Nathan, J. K., Chua, J. Y., Lee, S. W., Palmer, T. D., Steinberg, G. K., and Guzman, R. (2011). The CCR2/CCL2 interaction mediates the transendothelial recruitment of intravascularly delivered neural stem cells to the ischemic brain. Stroke 42, 2923-2931.

Antonucci, F., Turola, E., Riganti, L. Caleo, M., Gabrielli, M., Perrotta, C., Novellino, L., Clementi, E., Giussani, P., Viani, P., Matteoli, M., and
Verderio, C. (2012). Microvesicles released from microglia stimulate synaptic activity via enhanced sphingolipid metabolism. EMBO J. 31, 1231-1240.

Antonyak, M. A., Li, B., Boroughs, L. K., Johnson, J. L., Druso, J. E., Bryant, K. L., Holowka, D. A., and Cerione, R. A. (2011). Cancer cell-derived microvesicles induce transformation by transferring tissue transglutaminase and fibronectin to recipient cells. Proc. Natl. Acad. Sci. U.S.A. 108, 4852-4857.

Bacigaluppi, M., Pluchino, S., Peruzzotti-Jametti, L., Kilic, E., Kilic, U. Salani, G., Brambilla, E., West, M. J., Comi, G., Martino, G., and Hermann, D. M. (2009). Delayed postischaemic neuroprotection following systemic neural stem cell transplantation involves multiple mechanisms. Brain 132, 2239-2251. 
Bakhti, M., Winter, C., and Simons, M. (2011). Inhibition of myelin membrane sheath formation by oligodendrocyte-derived exosomelike vesicles. J. Biol. Chem. 286, 787-796.

Balaj, L., Lessard, R., Dai, L., Cho, Y. J., Pomeroy, S. L., Breakefield, X. O., and Skog, J. (2011). Tumour microvesicles contain retrotransposon elements and amplified oncogene sequences. Nat. Commun. 2, 180.

Bartel, D. P. (2009). MicroRNAs: target recognition and regulatory functions. Cell 136, 215-233.

Bhatnagar, S., Shinagawa, K., Castellino, F. J., and Schorey, J. S. (2007). Exosomes released from macrophages infected with intracellular pathogens stimulate a proinflammatory response in vitro and in vivo. Blood 110, 3234-3244.

Bianco, F., Perrotta, C., Novellino, L., Francolini, M., Riganti, L., Menna, E., Saglietti, L., Schuchman, E. H., Furlan, R., Clementi, E., Matteoli, M., and Verderio, C. (2009). Acid sphingomyelinase activity triggers microparticle release from glial cells. EMBO J. 28, 1043-1054.

Bianco, F., Pravettoni, E., Colombo, A., Schenk, U., Moller, T., Matteoli, M., and Verderio, C. (2005). Astrocyte-derived ATP induces vesicle shedding and IL-1 beta release from microglia. J. Immunol. 174, 7268-7277.

Blalock, J. E. (1994). The syntax of immune-neuroendocrine communication. Immunol. Today 15, 504-511.

Bobrie, A., Colombo, M., Raposo, G., and Thery, C. (2011). Exosome secretion: molecular mechanisms and roles in immune responses. Traffic 12, 1659-1668.

Boulanger, L. M., Huh, G. S., and Shatz, C. J. (2001). Neuronal plasticity and cellular immunity: shared molecular mechanisms. Curr. Opin. Neurobiol. 11, 568-578.

Bradl, M. (1996). Immune control of the brain. Springer Semin. Immunopathol. 18, 35-49.

Brown, K., Sacks, S. H., and Wong, W. (2008). Extensive and bidirectional transfer of major histocompatibility complex class II molecules between donor and recipient cells in vivo following solid organ transplantation. FASEB J. 22, 3776-3784.

Bruno, S., Grange, C., Deregibus, M. C., Calogero, R. A., Saviozzi, S., Collino, F., Morando, L., Busca, A., Falda, M., Bussolati, B., Tetta, C., and Camussi, G. (2009). Mesenchymal stem cellderived microvesicles protect against acute tubular injury. J. Am. Soc. Nephrol. 20, 1053-1067.

Bu, N., Wu, H., Sun, B., Zhang, G., Zhan, S., Zhang, R., and Zhou, L. (2011). Exosome-loaded dendritic cells elicit tumor-specific CD8+ cytotoxic T cells in patients with glioma. J. Neurooncol. 104, 659-667.

Bulloj, A., Leal, M. C., Xu, H., Castano, E. M., and Morelli, L. (2010). Insulin-degrading enzyme sorting in exosomes: a secretory pathway for a key brain amyloid-beta degrading protease. J. Alzheimers Dis. 19, 79-95.

Butovsky, O., Ziv, Y., Schwartz, A., Landa, G., Talpalar, A. E., Pluchino, S., Martino, G., and Schwartz, M. (2006). Microglia activated by IL-4 or IFN-gamma differentially induce neurogenesis and oligodendrogenesis from adult stem/progenitor cells. Mol. Cell. Neurosci. 31, 149-160.

Camussi, G., Deregibus, M. C., and Tetta, C. (2010). Paracrine/endocrine mechanism of stem cells on kidney repair: role of microvesicle-mediated transfer of genetic information. Curr. Opin. Nephrol. Hypertens. 19, 7-12.

Capone, C., Frigerio, S., Fumagalli, S., Gelati, M., Principato, M. C., Storini, C., Montinaro, M., Kraftsik, R., De Curtis, M., Parati, E., and De Simoni, M. G. (2007). Neurosphere-derived cells exert a neuroprotective action by changing the ischemic microenvironment. PLOS ONE 2, e373. doi:10.1371/journal.pone.0000373

Carrithers, M. D., Visintin, I., Kang, S. J., and Janeway, C. A. Jr. (2000). Differential adhesion molecule requirements for immune surveillance and inflammatory recruitment. Brain 123, 1092-1101.

Chaput, N., and Thery, C. (2011). Exosomes: immune properties and potential clinical implementations. Semin. Immunopathol. 33, 419-440.

Chen, T. S., Lai, R. C., Lee, M. M., Choo, A. B., Lee, C. N., and Lim, S. K. (2010). Mesenchymal stem cell secretes microparticles enriched in pre-microRNAs. Nucleic Acids Res. 38, 215-224.

Chen, X., Liang, H., Zhang, J., Zen, K., and Zhang, C. Y. (2012). Secreted microRNAs: a new form of intercellular communication. Trends Cell Biol. 22, 125-132.

Chironi, G. N., Boulanger, C. M., Simon, A., Dignat-George, F., Freyssinet, J. M., and Tedgui, A. (2009). Endothelial microparticles in diseases. Cell Tissue Res. 335, 143-151.

Ciesla, M., Skrzypek, K., Kozakowska, M., Loboda, A., Jozkowicz, A., and Dulak, J. (2011). MicroRNAs as biomarkers of disease onset. Anal. Bioanal. Chem. 401, 2051-2061.

Clayton, A., Court, J., Navabi, H., Adams, M., Mason, M. D., Hobot, J. A., Newman, G. R., and Jasani, B. (2001). Analysis of antigen presenting cell derived exosomes, based on immuno-magnetic isolation and flow cytometry. J. Immunol. Methods 247, 163-174.

Clayton, A., and Mason, M. D. (2009). Exosomes in tumour immunity. Curr. Oncol. 16, 46-49.

Clayton, A., Mitchell, J. P., Court, J., Mason, M. D., and Tabi, Z. (2007). Human tumor-derived exosomes selectively impair lymphocyte responses to interleukin-2. Cancer Res. 67, 7458-7466.

Cocucci, E., Racchetti, G., and Meldolesi, J. (2009). Shedding microvesicles: artefacts no more. Trends Cell Biol. 19, 43-51.

Collino, F., Deregibus, M. C., Bruno, S., Sterpone, L., Aghemo, G., Viltono, L., Tetta, C., and Camussi, G. (2010). Microvesicles derived from adult human bone marrow and tissue specific mesenchymal stem cells shuttle selected pattern of miRNAs. PLoS ONE 5, el1803. doi:10.1371/journal.pone.0011803

Coltel, N., Combes, V., Wassmer, S. C., Chimini, G., and Grau, G. E. (2006). Cell vesiculation and immunopathology: implications in cerebral malaria. Microbes Infect. 8 , 2305-2316.

Combes, V., Coltel, N., Alibert, M., Van Eck, M., Raymond, C., Juhan-Vague, I., Grau, G. E., and Chimini, G. (2005). ABCAl gene deletion protects against cerebral malaria: potential pathogenic role of microparticles in neuropathology. Am. J. Pathol. 166, 295-302.

Combes, V., Coltel, N., Faille, D., Wassmer, S. C., and Grau, G. E. (2006) Cerebral malaria: role of microparticles and platelets in alterations of the blood-brain barrier. Int. J. Parasitol. 36, 541-546.

Combes, V., El-Assaad, F., Faille, D. Jambou, R., Hunt, N. H., and Grau, G. E. (2010). Microvesiculation and cell interactions at the brain-endothelial interface in cerebral malaria pathogenesis. Prog. Neurobiol. 91, 140-151.

Croxford, J. L., Feldmann, M. Chernajovsky, Y., and Baker, D. (2001). Different therapeutic outcomes in experimental allergic encephalomyelitis dependent upon the mode of delivery of IL-10: a comparison of the effects of protein, adenoviral or retroviral IL-10 delivery into the central nervous system. J. Immunol. 166 , 4124-4130.

Cuatico, W., Woldron, R. Jr., and Tyschenko, W. (1977). Biochemical evidence for viral-like characteristics in cerebrospinal fluids of brain tumor patients. Cancer 39, 2240-2246.

Cusimano, M., Biziato, D., Brambilla, E., Donega, M., Alfaro-Cervello, C., Snider, S., Salani, G., Pucci, F., Comi, G., Garcia-Verdugo, J. M., De Palma, M., Martino, G., and Pluchino, S. (2012). Transplanted neural stem/precursor cells instruct phagocytes and reduce secondary tissue damage in the injured spinal cord. Brain 135, 447-460.

Daadi, M. M., Davis, A. S., Arac, A., Li, Z., Maag, A. L., Bhatnagar, R., Jiang, K., Sun, G., Wu, J. C., and Steinberg, G. K. (2010). Human neural stem cell grafts modify microglial response and enhance axonal sprouting in neonatal hypoxic-ischemic brain injury. Stroke 41, 516-523.

Darsalia, V., Kallur, T., and Kokaia, Z. (2007). Survival, migration and neuronal differentiation of human fetal striatal and cortical neural stem cells grafted in stroke-damaged rat striatum. Eur. J. Neurosci. 26, 605-614.

De Smaele, E., Ferretti, E., and Gulino, A. (2010). MicroRNAs as biomarkers for CNS cancer and other disorders. Brain Res. 1338, 100-111.

de Vrij, J., Kwappenberg, K. M. C., Maas, S. L. N., Kleijn, A., Lamfers, M. L., Dirven, C. M. F., Schilham, M. W., and Broekman, M. L. D. (2011). Immune-modulatory properties of glioblastoma multiforme exosomes. Neuro-oncology 13, iii30-iii33.

Denzer, K., Van Eijk, M., Kleijmeer, M. J., Jakobson, E., De Groot, C., and Geuze, H. J. (2000). Follicular dendritic cells carry MHC class II-expressing microvesicles at their surface. J. Immunol. 165, 1259-1265.

Deregibus, M. C., Cantaluppi, V., Calogero, R., Lo Iacono, M., Tetta, C., Biancone, L., Bruno, S., Bussolati, B., and Camussi, G. (2007). Endothelial progenitor cell derived microvesicles activate an angiogenic program in endothelial cells by a horizontal transfer of mRNA. Blood 110, 2440-2448.

Dinger, M. E., Mercer, T. R., and Mattick, J. S. (2008). RNAs as extracellular signaling molecules. J. Mol. Endocrinol. 40, 151-159.

Doring, A., and Yong, V. W. (2011). The good, the bad and the ugly. Macrophages/microglia with a focus on myelin repair. Front. Biosci. (Schol. Ed.) 3, 846-856. 
Einstein, O., Fainstein, N., Vaknin, I., Mizrachi-Kol, R., Reihartz, E., Grigoriadis, N., Lavon, I., Baniyash, M., Lassmann, H., and Ben-Hur, T. (2007). Neural precursors attenuate autoimmune encephalomyelitis by peripheral immunosuppression. Ann. Neurol. 61, 209-218.

Einstein, O., Karussis, D., Grigoriadis, N., Mizrachi-Kol, R., Reinhartz, E., Abramsky, O., and Ben-Hur, T. (2003). Intraventricular transplantation of neural precursor cell spheres attenuates acute experimental allergic encephalomyelitis. Mol. Cell. Neurosci. 24, 1074-1082.

Emmanouilidou, E., Melachroinou, K., Roumeliotis, T., Garbis, S. D., Ntzouni, M., Margaritis, L. H., Stefanis, L., and Vekrellis, K. (2010). Cell-produced alpha-synuclein is secreted in a calcium-dependent manner by exosomes and impacts neuronal survival. J. Neurosci. 30, 6838-6851.

Escola, J. M., Kleijmeer, M. J., Stoorvogel, W., Griffith, J. M., Yoshie, O., and Geuze, H. J. (1998). Selective enrichment of tetraspan proteins on the internal vesicles of multivesicular endosomes and on exosomes secreted by human B-lymphocytes. J. Biol. Chem. 273, 20121-20127.

Escudier, B., Dorval, T., Chaput, N., Andre, F., Caby, M. P., Novault, S., Flament, C., Leboulaire, C., Borg, C., Amigorena, S., Boccaccio, C., Bonnerot, C., Dhellin, O., Movassagh, M., Piperno, S., Robert, C., Serra, V., Valente, N., Le Pecq, J. B., Spatz, A., Lantz, O., Tursz, T., Angevin, E., and Zitvogel, L. (2005). Vaccination of metastatic melanoma patients with autologous dendritic cell (DC) derived-exosomes: results of thefirst phase I clinical trial. $J$. Transl. Med. 3, 10.

Fainstein, N., Vaknin, I., Einstein, O., Zisman, P., Ben Sasson, S. Z., Baniyash, M., and Ben-Hur, T. (2008). Neural precursor cells inhibit multiple inflammatory signals. Mol. Cell. Neurosci. 39, 335-341.

Faure, J., Lachenal, G., Court, M., Hirrlinger, J., Chatellard-Causse, C., Blot, B., Grange, J., Schoehn, G., Goldberg, Y., Boyer, V., Kirchhoff, F., Raposo, G., Garin, J., and Sadoul, R. (2006). Exosomes are released by cultured cortical neurones. Mol. Cell. Neurosci. 31, 642-648.

Fevrier, B., Vilette, D., Archer, F., Loew, D., Faigle, W., Vidal, M., Laude, H., and Raposo, G. (2004). Cells release prions in association with exosomes. Proc. Natl. Acad. Sci. U.S.A. 101, 9683-9688.
Fitzner, D., Schnaars, M., Van Rossum, D., Krishnamoorthy, G., Dibaj, P., Bakhti, M., Regen, T., Hanisch, U. K., and Simons, M. (2011). Selective transfer of exosomes from oligodendrocytes to microglia by macropinocytosis. J. Cell. Sci. 124, 447-458.

Gastpar, R., Gehrmann, M., Bausero, M. A., Asea, A., Gross, C., Schroeder, J. A., and Multhoff, G. (2005). Heat shock protein 70 surface-positive tumor exosomes stimulate migratory and cytolytic activity of natural killer cells. Cancer Res. 65, 5238-5247.

Gatti, S., Bruno, S., Deregibus, M. C., Sordi, A., Cantaluppi, V., Tetta, C., and Camussi, G. (2011). Microvesicles derived from human adult mesenchymal stem cells protect against ischaemia-reperfusioninduced acute and chronic kidney injury. Nephrol. Dial. Transplant. 26, 1474-1483.

Gerdes, H. H., and Carvalho, R. N. (2008). Intercellular transfer mediated by tunneling nanotubes. Curr. Opin. Cell Biol. 20, 470-475.

Gibbings, D. J., Ciaudo, C., Erhardt, M., and Voinnet, O. (2009). Multivesicular bodies associate with components of miRNA effector complexes and modulate miRNA activity. Nat. Cell Biol. 11, 1143-1149.

Gilbertson, R. J., and Rich, J. N. (2007). Making a tumour's bed: glioblastoma stem cells and the vascular niche. Nat. Rev. Cancer 7, 733-736.

Goedert, M., Clavaguera, F., and Tolnay, M. (2010). The propagation of prion-like protein inclusions in neurodegenerative diseases. Trends Neurosci. 33, 317-325.

Gourzones, C., Gelin, A., Bombik, I., Klibi, J., Verillaud, B., Guigay, J., Lang, P., Temam, S., Schneider, V., Amiel, C., Baconnais, S., Jimenez, A. S., and Busson, P. (2010). Extracellular release and blood diffusion of BART viral micro-RNAs produced by EBV-infected nasopharyngeal carcinoma cells. Virol. J. 7, 271.

Gousset, K., Schiff, E., Langevin, C., Marijanovic, Z., Caputo, A., Browman, D. T., Chenouard, N., De Chaumont, F., Martino, A., Enninga, J., Olivo-Marin, J. C., Mannel, D., and Zurzolo, C. (2009). Prions hijack tunnelling nanotubes for intercellular spread. Nat. Cell Biol. 11, 328-336.

Graeber, M. B. (2010). Changing face of microglia. Science 330, 783-788.

Graeber, M. B., Li, W., and Rodriguez, M. L. (2011). Role of microglia in CNS inflammation. FEBS Lett. 585 , 3798-3805.
Graner, M.W. (2011). "Brain tumor exosomes and microvesicles: pleiotropic effects from tiny cellular surrogates,' in Molecular Targets of CNS Tumors, ed. M. Garami (InTech). Available at: http://www.intechopen.com/ books/molecular-targets-of-cns-tu mors/brain-tumor-exosomes-andmicrovesicles-pleiotropic-effectsfrom-tiny-cellular-surrogates

Graner, M. W.,Alzate, O., Dechkovskaia, A. M., Keene, J. D., Sampson, J. H., Mitchell, D. A., and Bigner, D. D. (2009). Proteomic and immunologic analyses of brain tumor exosomes. FASEB J. 23, 1541-1557.

Griffiths, M., Neal, J. W., and Gasque, P. (2007). Innate immunity and protective neuroinflammation: new emphasis on the role of neuroimmune regulatory proteins. Int. Rev. Neurobiol. 82, 29-55.

Guescini, M., Genedani, S., Stocchi, V., and Agnati, L. F. (2010). Astrocytes and Glioblastoma cells release exosomes carrying mtDNA. J. Neural Transm. 117, 1-4.

Hawari, F. I., Rouhani, F. N., Cui, X., Yu, Z. X., Buckley, C., Kaler, M., and Levine, S. J. (2004). Release of full-length $55-\mathrm{kDa}$ TNF receptor 1 in exosome-like vesicles: a mechanism for generation of soluble cytokine receptors. Proc. Natl. Acad. Sci. U.S.A. 101, 1297-1302.

Hawkins, B. T., and Davis, T. P. (2005). The blood-brain barrier/neurovascular unit in health and disease. Pharmacol. Rev. 57, 173-185.

Hemmati, H. D., Nakano, I., Lazareff, J. A., Masterman-Smith, M., Geschwind, D. H., Bronner-Fraser, M., and Kornblum, H. I. (2003). Cancerous stem cells can arise from pediatric brain tumors. Proc. Natl. Acad. Sci. U.S.A. 100, 15178-15183.

Hergenreider, E., Heydt, S., Treguer, K., Boettger, T., Horrevoets, A. J., Zeiher, A. M., Scheffer, M. P., Frangakis, A. S., Yin, X., Mayr, M., Braun, T., Urbich, C., Boon, R. A., and Dimmeler, S. (2012). Atheroprotective communication between endothelial cells and smooth muscle cells through miRNAs. Nat. Cell Biol. 14, 249-256.

Herrera, M. B., Fonsato, V., Gatti, S., Deregibus, M. C., Sordi, A., Cantarella, D., Calogero, R., Bussolati, B., Tetta, C., and Camussi, G. (2010). Human liver stem cell-derived microvesicles accelerate hepatic regeneration in hepatectomized rats. J. Cell. Mol. Med. 14, 1605-1618.

Hsu, C., Morohashi, Y., Yoshimura, S., Manrique-Hoyos, N., Jung, S.,
Lauterbach, M. A., Bakhti, M., Gronborg, M., Mobius, W., Rhee, J., Barr, F. A., and Simons, M. (2010). Regulation of exosome secretion by Rab35 and its GTPase-activating proteins TBC1D10A-C. J. Cell Biol. 189, 223-232.

Hunter, M. P., Ismail, N., Zhang, X., Aguda, B. D., Lee, E. J., Yu, L., Xiao, T., Schafer, J., Lee, M. L., Schmittgen, T. D., Nana-Sinkam, S. P., Jarjoura, D., and Marsh, C. B. (2008). Detection of microRNA expression in human peripheral blood microvesicles. PLoS ONE 3, e3694. doi:10.1371/journal.pone.0003694

Huttner, H. B., Corbeil, D., Thirmeyer, C., Coras, R., Kohrmann, M., Mauer, C., Kuramatsu, J. B., Kloska, S. P., Doerfler, A., Weigel, D., Klucken, J., Winkler, J., Pauli, E., Schwab, S., Hamer, H. M., and Kasper, B. S. (2012). Increased membrane shedding - indicated by an elevation of CD133-enriched membrane particles -into the CSF in partial epilepsy. Epilepsy Res. 99, 101-106.

Huttner, H. B., Janich, P., Kohrmann, M., Jaszai, J., Siebzehnrubl, F., Blumcke, I., Suttorp, M., Gahr, M., Kuhnt, D., Nimsky, C., Krex, D., Schackert, G., Lowenbruck, K., Reichmann, H., Juttler, E., Hacke, W., Schellinger, P. D., Schwab, S., Wilsch-Brauninger, M., Marzesco, A. M., and Corbeil, D. (2008). The stem cell marker prominin-1/CD133 on membrane particles in human cerebrospinal fluid offers novel approaches for studying central nervous system disease. Stem Cells 26, 698-705.

Iero, M., Valenti, R., Huber, V., Filipazzi, P., Parmiani, G., Fais, S., and Rivoltini, L. (2008). Tumour-released exosomes and their implications in cancer immunity. Cell Death Differ. 15, 80-88.

Imitola, J., Raddassi, K., Park, K. I., Mueller, F. J., Nieto, M., Teng, Y. D., Frenkel, D., Li, J., Sidman, R. L., Walsh, C. A., Snyder, E. Y., and Khoury, S. J. (2004). Directed migration of neural stem cells to sites of CNS injury by the stromal cell-derived factor lalpha/CXC chemokine receptor 4 pathway. Proc. Natl. Acad. Sci. U.S.A. 101, 18117-18122.

Jacques, T. S., Swales, A., Brzozowski, M. J., Henriquez, N. V., Linehan, J. M., Mirzadeh, Z., O'Malley, C., Naumann, H., AlvarezBuylla, A., and Brandner, S. (2010). Combinations of genetic mutations in the adult neural stem cell compartment determine brain tumour phenotypes. EMBO J. 29, 222-235. 
Jung, K. H., Chu, K., Lee, S. T., Park, H. K., Bahn, J. J., Kim, D. H., Kim, J. H., Kim, M., Kun Lee, S., and Roh, J. K. (2009). Circulating endothelial microparticles as a marker of cerebrovascular disease. Ann. Neurol. 66, 191-199.

Jy, W., Minagar, A., Jimenez, J. J., Sheremata, W. A., Mauro, L. M., Horstman, L. L., Bidot, C., and Ahn, Y. S. (2004). Endothelial microparticles (EMP) bind and activate monocytes: elevated EMP-monocyte conjugates in multiple sclerosis. Front. Biosci. 9, 3137-3144.

Kang, D., Oh, S., Ahn, S. M., Lee, B. H., and Moon, M. H. (2008). Proteomic analysis of exosomes from human neural stem cells by flow fieldflow fractionation and nanoflow liquid chromatography-tandem mass spectrometry. J. Proteome Res. 7, 3475-3480.

Kettenmann, H. (2007). Neuroscience: the brain's garbage men. Nature 446 , 987-989.

Kettenmann, H., Hanisch, U. K., Noda, M., and Verkhratsky, A. (2011). Physiology of microglia. Physiol. Rev. 91, 461-553.

Kilic, E., Kilic, U., Bacigaluppi, M., Guo, Z., Abdallah, N. B., Wolfer, D. P., Reiter, R. J., Hermann, D. M., and Bassetti, C. L. (2008). Delayed melatonin administration promotes neuronal survival, neurogenesis and motor recovery, and attenuates hyperactivity and anxiety after mild focal cerebral ischemia in mice. J Pineal Res. 45, 142-148.

Kim, H. M., Hwang, D. H., Lee, J. E., Kim, S. U., and Kim, B. G. (2009a). Ex vivo VEGF delivery by neural stem cells enhances proliferation of glial progenitors, angiogenesis, and tissue sparing after spinal cord injury. PLoS ONE 4, e4987. doi:10.1371/journal.pone.0004987

Kim, S. Y., Cho, H. S., Yang, S. H., Shin, J. Y., Kim, J. S., and Park, C. G. (2009b). Exosomes secreted from human neural stem cells suppress $\mathrm{T}$ cell activation. J. Immunol. 182, 90.33 .

Knight, J. C., Scharf, E. L., and MaoDraayer, Y. (2010). Fas activation increases neural progenitor cell survival. J. Neurosci. Res. 88, 746-757.

Koppler, B., Cohen, C., Schlondorff, D., and Mack, M. (2006). Differential mechanisms of microparticle transfer toB cells and monocytes: anti-inflammatory propertiesof microparticles. Eur. J. Immunol. 36, 648-660.

Kosaka, N., Iguchi, H., Yoshioka, Y., Takeshita, F., Matsuki, Y., and Ochiya, T. (2010). Secretory mechanisms and intercellular transfer of microRNAs in living cells. J. Biol. Chem. 285, 17442-17452.

Lachenal, G., Pernet-Gallay, K., Chivet, M., Hemming, F. J., Belly, A., Bodon, G., Blot, B., Haase, G., Goldberg, Y., and Sadoul, R. (2011). Release of exosomes from differentiated neurons and its regulation by synaptic glutamatergic activity. Mol. Cell. Neurosci. 46, 409-418.

Lai, R. C., Arslan, F., Lee, M. M., Sze, N. S., Choo, A., Chen, T. S., Salto-Tellez, M., Timmers, L., Lee, C. N., El Oakley, R. M., Pasterkamp, G., De Kleijn, D. P., and Lim, S. K. (2010). Exosome secreted by MSC reduces myocardial ischemia/reperfusion injury. Stem Cell Res. 4, 214-222.

Lalancette-Hebert, M., Gowing, G., Simard, A., Weng, Y. C., and Kriz, J. (2007). Selective ablation of proliferating microglial cells exacerbates ischemic injury in the brain. J. Neurosci. 27, 2596-2605.

Lee, S. T., Chu, K., Jung, K. H., Kim, S. J., Kim, D. H., Kang, K. M., Hong, N. H., Kim, J. H., Ban, J. J., Park, H. K., Kim, S. U., Park, C. G., Lee, S. K., Kim, M., and Roh, J. K. (2008). Anti-inflammatory mechanism of intravascular neural stem cell transplantation in haemorrhagic stroke. Brain 131, 616-629.

Liu, C., Yu, S., Zinn, K., Wang, J., Zhang, L., Jia, Y., Kappes, J. C., Barnes, S., Kimberly, R. P., Grizzle, W. E., and Zhang, H. G. (2006). Murine mammary carcinoma exosomes promote tumor growth by suppression of NK cell function. J. Immunol. 176, 1375-1385.

Lowery-Nordberg, M., Eaton, E., Gonzalez-Toledo, E., Harris, M. K., Chalamidas, K., Mcgee-Brown, J., Ganta, C. V., Minagar, A., Cousineau, D., and Alexander, J. S. (2011). The effects of high dose interferonbetala on plasma microparticles: correlation with MRI parameters. J. Neuroinflammation 8, 43.

MacKenzie, A., Wilson, H. L., KissToth, E., Dower, S. K., North, R. A., and Surprenant, A. (2001). Rapid secretion of interleukin-1beta by microvesicle shedding. Immunity $15,825-835$.

Mae, M., Armulik, A., and Betsholtz, C. (2011). Getting to know the cast cellular interactions and signaling at the neurovascular unit. Curr. Pharm. Des. 17, 2750-2754.

Mangeot, P. E., Dollet, S., Girard, M., Ciancia, C., Joly, S., Peschanski, M., and Lotteau, V. (2011). Protein
Transfer Into Human Cells by VSVG-induced Nanovesicles. Mol. Ther 19, 1656-1666.

Martino, G., and Pluchino, S. (2006) The therapeutic potential of neural stem cells. Nat. Rev. Neurosci. 7, 395-406.

Martino, G., Pluchino, S., Bonfanti, L., and Schwartz, M. (2011). Brain regeneration in physiology and pathology: the immune signature driving therapeutic plasticity of neural stem cells. Physiol. Rev. 91, 1281-1304.

Marzesco, A. M., Janich, P., WilschBrauninger, M., Dubreuil, V., Langenfeld, K., Corbeil, D., and Huttner, W. B. (2005). Release of extracellular membrane particles carrying the stem cell marker prominin1 (CD133) from neural progenitors and other epithelial cells. J. Cell Sci. 118, 2849-2858.

Maxfield, F. R., and McGraw, T. E. (2004). Endocytic recycling. Nat. Rev. Mol. Cell Biol. 5, 121-132.

Meckes, D. G. Jr., Shair, K. H., Marquitz, A. R., Kung, C. P., Edwards, R. H., and Raab-Traub, N. (2010). Human tumor virus utilizes exosomes for intercellular communication. Proc. Natl. Acad. Sci. U.S.A. 107, 20370-20375.

Miljkovic, D., Timotijevic, G., and Stojkovic, M. M. (2011). Astrocytes in the tempest of multiple sclerosis. FEBS Lett. 585, 3781-3788.

Minagar, A., Jy, W., Jimenez, J. J., Sheremata, W. A., Mauro, L. M., Mao, W. W., Horstman, L. L., and Ahn, Y. S. (2001). Elevated plasma endothelial microparticles in multiple sclerosis. Neurology 56, 1319-1324.

Ming, G. L., and Song, H. (2011). Adult neurogenesis in the mammalian brain: significant answers and significant questions. Neuron 70, 687-702.

Mittelbrunn, M., Gutierrez-Vazquez, C. Villarroya-Beltri, C., Gonzalez, S., Sanchez-Cabo, F., Gonzalez, M. A., Bernad, A., and Sanchez-Madrid, F. (2011). Unidirectional transfer of microRNA-loaded exosomes from $\mathrm{T}$ cells to antigen-presenting cells. Nat. Commun. 2, 282.

Miyanishi, M., Tada, K., Koike, M. Uchiyama, Y., Kitamura, T., and Nagata, S. (2007). Identification of Tim 4 as a phosphatidylserine receptor. Nature 450, 435-439.

Morel, O., Morel, N., Jesel, L., Freyssinet, J. M., and Toti, F. (2011). Microparticles: a critical component in the nexus between inflammation, immunity, and thrombosis. Semin. Immunopathol. 33, 469-486.
Muntasell, A., Berger, A. C., and Roche, P. A. (2007). T cell-induced secretion of MHC class II-peptide complexes on B cell exosomes. EMBO J. 26, 4263-4272.

Nguyen, L. V., Vanner, R., Dirks, P., and Eaves, C. J. (2012). Cancer stem cells: an evolving concept. Nat. Rev. Cancer 12, 133-143.

O'Connell, R. M., Rao, D. S., Chaudhuri, A. A., and Baltimore, D. (2010). Physiological and pathological roles for microRNAs in the immune system. Nat. Rev. Immunol. 10, 111-122.

Pegtel, D. M., Cosmopoulos, K. Thorley-Lawson, D. A., Van Eijndhoven, M. A., Hopmans, E. S., Lindenberg, J. L., De Gruijl, T. D., Wurdinger, T., and Middeldorp, J. M. (2010). Functional delivery of viral miRNAs via exosomes. Proc. Natl. Acad. Sci. U.S.A. 107, 6328-6333.

Pelloski, C. E., Ballman, K. V., Furth, A. F., Zhang, L., Lin, E., Sulman, E. P., Bhat, K., Mcdonald, J. M., Yung, W. K., Colman, H., Woo, S. Y., Heimberger, A. B., Suki, D., Prados, M. D., Chang, S. M., Barker, F. G. II, Buckner, J. C., James, C. D., and Aldape, K. (2007). Epidermal growth factor receptor variant III status defines clinically distinct subtypes of glioblastoma. J. Clin. Oncol. 25, 2288-2294

Pluchino, S., Gritti, A., Blezer, E., Amadio, S., Brambilla, E., Borsellino, G., Cossetti, C., Del Carro, U., Comi, G., T Hart, B., Vescovi, A., and Martino, G. (2009a). Human neural stem cells ameliorate autoimmune encephalomyelitis in nonhuman primates. Ann. Neurol. 66, 343-354.

Pluchino, S., Zanotti, L., Brambilla, E., Rovere-Querini, P., Capobianco, A., Alfaro-Cervello, C., Salani, G., Cossetti, C., Borsellino, G., Battistini, L., Ponzoni, M., Doglioni, C., Garcia-Verdugo, J. M., Comi, G., Manfredi, A. A., and Martino, G. (2009b). Immune regulatory neural stem/precursor cells protect from central nervous system autoimmunity by restraining dendritic cell function. PLoS ONE 4, e5959. doi:10.1371/journal.pone. 0005959

Pluchino, S., Zanotti, L., Rossi, B., Brambilla, E., Ottoboni, L., Salani, G., Martinello, M., Cattalini, A., Bergami, A., Furlan, R., Comi, G., Constantin, G., and Martino, G. (2005). Neurosphere-derived multipotent precursors promote neuroprotection by an immunomodulatory mechanism. Nature 436, 266-271. 
Potolicchio, I., Carven, G. J., Xu, X., Stipp, C., Riese, R. J., Stern, L. J., and Santambrogio, L. (2005). Proteomic analysis of microglia-derived exosomes: metabolic role of the aminopeptidase CD13 in neuropeptide catabolism. J. Immunol. 175, 2237-2243.

Putz, U., Howitt, J., Lackovic, J., Foot, N., Kumar, S., Silke, J., and Tan, S. S. (2008). Nedd4 family-interacting protein 1 (Ndfipl) is required for the exosomal secretion of $\mathrm{Nedd} 4$ family proteins. J. Biol. Chem. 283, 32621-32627.

Quesenberry, P. J., and Aliotta, J. M. (2008). The paradoxical dynamism of marrow stem cells: considerations of stem cells, niches, and microvesicles. Stem Cell. Rev. 4, 137-147.

Rabelink, T. J., De Boer, H. C., and Van Zonneveld, A. J. (2010). Endothelial activation and circulating markers of endothelial activation in kidney disease. Nat. Rev. Nephrol. 6, 404-414.

Rabinowits, G., Gercel-Taylor, C., Day, J. M., Taylor, D. D., and Kloecker, G. H. (2009). Exosomal microRNA: a diagnostic marker for lung cancer. Clin. Lung Cancer 10, 42-46.

Raivich, G., and Banati, R. (2004). Brain microglia and blood-derived macrophages: molecular profiles and functional roles in multiple sclerosis and animal models of autoimmune demyelinating disease. Brain Res. Brain Res. Rev. 46, 261-281.

Rajendran, L., Honsho, M., Zahn, T. R., Keller, P., Geiger, K. D., Verkade, P., and Simons, K. (2006). Alzheimer's disease beta-amyloid peptides are released in association with exosomes. Proc. Natl. Acad. Sci. U.S.A. 103, 11172-11177.

Ransohoff, R. M., and Cardona, A. E. (2010). The myeloid cells of the central nervous system parenchyma. Nature 468, 253-262.

Raposo, G., Nijman, H. W., Stoorvogel, W., Liejendekker, R., Harding, C. V., Melief, C. J., and Geuze, H. J. (1996). B lymphocytes secrete antigen-presenting vesicles. J. Exp. Med. 183, 1161-1172.

Ratajczak, J., Miekus, K., Kucia, M., Zhang, J., Reca, R., Dvorak, P., and Ratajczak, M. Z. (2006). Embryonic stem cell-derived microvesicles reprogram hematopoietic progenitors: evidence for horizontal transfer of mRNA and protein delivery. Leukemia 20, 847-856.

Rock, R. B., and Peterson, P. K. (2006). Microglia as a pharmacological target in infectious and inflammatory diseases of the brain. J. Neuroimmune Pharmacol. 1, 117-126.
Sabin, K. Z., Lebert, D., Thibado, V., Rovin, R., Lawrence, J., and Winn, R. (2011). Glioblastoma-derived exosomes contribute to tumor immune evasion. Neuro-oncology 13, iii30iii33.

Saman, S., Kim, W., Raya, M., Visnick, Y., Miro, S., Jackson, B., Mckee, A. C., Alvarez, V. E., Lee, N. C., and Hall, G. F. (2012). Exosome-associated tau is secreted in tauopathy models and is selectively phosphorylated in cerebrospinal fluid (CSF) in early Alzheimer's Disease. J. Biol. Chem. 287, 3842-3849.

Sanai, N., Alvarez-Buylla, A., and Berger, M. S. (2005). Neural stem cells and the origin of gliomas. N. Engl. J. Med. 353, 811-822.

Schiera, G., Proia, P., Alberti, C., Mineo, M., Savettieri, G., and Di Liegro, I. (2007). Neurons produce FGF2 and VEGF and secrete them at least in part by shedding extracellular vesicles. J. Cell. Mol. Med. 11, 1384-1394.

Segura, E., Amigorena, S., and Thery, C. (2005a). Mature dendritic cells secrete exosomes with strong ability to induce antigen-specific effector immune responses. Blood Cells Mol. Dis. 35, 89-93.

Segura, E., Nicco, C., Lombard, B., Veron, P., Raposo, G., Batteux, F., Amigorena, S., and Thery, C. (2005b). ICAM-1 on exosomes from mature dendritic cells is critical for efficient naive T-cell priming. Blood 106, 216-223.

Segura, E., Guerin, C., Hogg, N., Amigorena, S., and Thery, C. (2007). CD8+ dendritic cells use LFA-1 to capture MHC-peptide complexes from exosomes in vivo. J. Immunol. 179, 1489-1496.

Sharples, R. A., Vella, L. J., Nisbet, R. M., Naylor, R., Perez, K., Barnham, K. J., Masters, C. L., and Hill, A. F. (2008). Inhibition of gamma-secretase causes increased secretion of amyloid precursor protein C-terminal fragments in association with exosomes. FASEB J. 22, 1469-1478.

Sheremata, W. A., Jy, W., Delgado, S., Minagar, A., Mclarty, J., and Ahn, Y. (2006). Interferon-betala reduces plasma CD31+ endothelial microparticles $(\mathrm{CD} 31+\mathrm{EMP})$ in multiple sclerosis. J. Neuroinflammation 3, 23.

Simak, J., Gelderman, M. P., Yu, H., Wright, V., and Baird, A. E. (2006). Circulating endothelial microparticles in acute ischemic stroke: a link to severity, lesion volume and outcome. J. Thromb. Haemost. 4, 1296-1302.

Simons, M., and Raposo, G. (2009). Exosomes-vesicular carriers for intercellular communication. Curr. Opin. Cell Biol. 21, 575-581.

Singh, S. K., Hawkins, C., Clarke, I. D., Squire, J. A., Bayani, J., Hide, T., Henkelman, R. M., Cusimano, M. D., and Dirks, P. B. (2004). Identification of human brain tumour initiating cells. Nature 432, 396-401.

Skog, J., Wurdinger, T., Van Rijn, S., Meijer, D. H., Gainche, L., Sena-Esteves, M., Curry, W. T. Jr., Carter, B. S., Krichevsky, A. M., and Breakefield, X. O. (2008). Glioblastoma microvesicles transport RNA and proteins that promote tumour growth and provide diagnostic biomarkers. Nat. Cell Biol. 10, 1470-1476.

Smalheiser, N. R. (2007). Exosomal transfer of proteins and RNAs at synapses in the nervous system. Biol. Direct 2, 35

Smalheiser, N. R. (2009). Do Neural Cells Communicate with Endothelial Cells via Secretory Exosomes and Microvesicles? Cardiovasc. Psychiatry Neurol. 2009, 383086.

Street, J. M., Barran, P. E., Mackay, C. L., Weidt, S., Balmforth, C., Walsh, T. S., Chalmers, R. T., Webb, D. J., and Dear, J. W. (2012). Identification and proteomic profiling of exosomes in human cerebrospinal fluid. J. Transl. Med. 10, 5.

Streit, W. J., and Kincaid-Colton, C. A (1995). The brain's immune system. Sci. Am. 273, 54-55; 58-61.

Sun, C., Zhang, H., Li, J., Huang, H., Cheng, H., Wang, Y., Li, P., and An, Y. (2010). Modulation of the major histocompatibility complex by neural stem cell-derived neurotrophic factors used for regenerative therapy in a rat model of stroke. J. Transl. Med. 8,77 .

Svensson, K. J., Kucharzewska, P., Christianson, H. C., Skold, S., Lofstedt, T., Johansson, M. C., Morgelin, M., Bengzon, J., Ruf, W., and Belting, M. (2011). Hypoxia triggers a proangiogenic pathway involving cancer cell microvesicles and PAR-2-mediated heparin-binding EGF signaling in endothelial cells. Proc. Natl. Acad. Sci. U.S.A. 108, 13147-13152.

Tamboli, I. Y., Barth, E., Christian, L., Siepmann, M., Kumar, S., Singh, S., Tolksdorf, K., Heneka, M. T., Lutjohann, D., Wunderlich, P., and Walter, J. (2010). Statins promote the degradation of extracellular amyloid \{beta\}peptide by microglia via stimulation of exosome-associated insulindegrading enzyme (IDE) secretion. J. Biol. Chem. 285, 37405-37414.

Taylor, A. R., Robinson, M. B., Gifondorwa, D. J., Tytell, M., and
Milligan, C. E. (2007). Regulation of heat shock protein 70 release in astrocytes: role of signaling kinases. Dev. Neurobiol. 67, 1815-1829.

Taylor, D. D., and Gercel-Taylor, C. (2008). MicroRNA signatures of tumor-derived exosomes as diagnostic biomarkers of ovarian cancer. Gynecol. Oncol. 110, 13-21.

Thery, C. (2011). Exosomes: secreted vesicles and intercellular communications. F1000 Biol. Rep. 3, 15.

Thery, C., Ostrowski, M., and Segura, E. (2009). Membrane vesicles as conveyors of immune responses. Nat. Rev. Immunol. 9, 581-593.

Thery, C., Regnault, A., Garin, J., Wolfers, J., Zitvogel, L., RicciardiCastagnoli, P., Raposo, G., and Amigorena, S. (1999). Molecular characterization of dendritic cellderived exosomes. Selective accumulation of the heat shock protein hsc73. J. Cell. Biol. 147, 599-610.

Trajkovic, K., Hsu, C., Chiantia, S., Rajendran, L., Wenzel, D., Wieland, F., Schwille, P., Brugger, B., and Simons, M. (2008). Ceramide triggers budding of exosome vesicles into multivesicular endosomes. Science 319, 1244-1247.

Trams, E. G., Lauter, C. J., Salem, N. Jr., and Heine, U. (1981). Exfoliation of membrane ecto-enzymes in the form of micro-vesicles. Biochim. Biophys. Acta 645, 63-70.

Tremblay, M. E., Stevens, B., Sierra, A., Wake, H., Bessis, A., and Nimmerjahn, A. (2011). The role of microglia in the healthy brain. J. Neurosci. 31, 16064-16069.

Trosko, J. E., and Chang, C. C. (1989). Stem cell theory of carcinogenesis. Toxicol. Lett. 49, 283-295.

Twiss, J. L., and Fainzilber, M. (2009). Ribosomes in axons-scrounging from the neighbors? Trends Cell Biol. 19, 236-243.

Uccelli, A., Moretta, L., and Pistoia, V. (2008). Mesenchymal stem cells in health and disease. Nat. Rev. Immunol. 8, 726-736.

Uchida, K., Mukai, M., Okano, H., and Kawase, T. (2004). Possible oncogenicity of subventricular zone neural stem cells: case report. $\mathrm{Neu}$ rosurgery 55, 977-978.

Valadi, H., Ekstrom, K., Bossios, A., Sjostrand, M., Lee, J. J., and Lotvall, J. O. (2007). Exosome-mediated transfer of mRNAs and microRNAs is a novel mechanism of genetic exchange between cells. Nat. Cell Biol. 9, 654-659.

Valenti, R., Huber, V., Filipazzi, P., Pilla, L., Sovena, G., Villa, A., Corbelli, A., Fais, S., Parmiani, G., and 
Rivoltini, L. (2006). Human tumorreleased microvesicles promote the differentiation of myeloid cells with transforming growth factor-betamediated suppressive activity on T lymphocytes. Cancer Res. 66, 9290-9298.

Valenti, R., Huber, V., Iero, M., Filipazzi, P., Parmiani, G., and Rivoltini, L. (2007). Tumor-released microvesicles as vehicles of immunosuppression. Cancer Res. 67, 2912-2915.

van der Vos, K. E., Balaj, L., Skog, J., and Breakefield, X. O. (2011). Brain tumor microvesicles: insights into intercellular communication in the nervous system. Cell. Mol. Neurobiol. 31, 949-959.

Vella, L. J., Sharples, R. A., Lawson, V. A., Masters, C. L., Cappai, R., and Hill, A. F. (2007). Packaging of prions into exosomes is associated with a novel pathway of PrP processing. J. Pathol. 211, 582-590.

Vella, L. J., Sharples, R. A., Nisbet, R. M., Cappai, R., and Hill, A. F. (2008). The role of exosomes in the processing of proteins associated with neurodegenerative diseases. Eur. Biophys. J. 37, 323-332.

Vescovi, A. L., Galli, R., and Reynolds, B. A. (2006). Brain tumour stem cells. Nat. Rev. Cancer 6, 425-436.

Von Bartheld, C. S., and Altick, A. L. (2011). Multivesicular bodies in neurons: distribution, protein content, and trafficking functions. Prog. Neurobiol. 93, 313-340.

Wang, K., Zhang, S., Weber, J., Baxter, D., and Galas, D. J.
(2010). Export of microRNAs and microRNA-protective protein by mammalian cells. Nucleic Acids Res. 38, 7248-7259.

Wang, L., Shi, J., Van Ginkel, F. W., Lan, L., Niemeyer, G., Martin, D. R., Snyder, E. Y., and Cox, N. R. (2009). Neural stem/progenitor cells modulate immune responses by suppressing $\mathrm{T}$ lymphocytes with nitric oxide and prostaglandin E2. Exp. Neurol. 216, 177-183.

Wekerle, H., Linington, C., Lassmann, H., and Meyermann, R. (1986). Cellular immune reactivity within the CNS. Trends Neurosci. 9, 271-277.

Wieckowski, E., and Whiteside, T. L. (2006). Human tumor-derived vs dendritic cell-derived exosomes have distinct biologic roles and molecular profiles. Immunol. Res. 36, 247-254.

Wilson, E. H., Weninger, W., and Hunter, C. A. (2010). Trafficking of immune cells in the central nervous system. J. Clin. Invest. 120, 1368-1379.

Wolfers, J., Lozier, A., Raposo, G., Regnault, A., Thery, C., Masurier, C., Flament, C., Pouzieux, S., Faure, F., Tursz, T., Angevin, E., Amigorena, S., and Zitvogel, L. (2001). Tumorderived exosomes are a source of shared tumor rejection antigens for CTL cross-priming. Nat. Med. 7, 297-303.

Yang, I., Han, S. J., Kaur, G., Crane, C., and Parsa, A. T. (2010). The role of microglia in central nervous system immunity and glioma immunology. J. Clin. Neurosci. 17, 6-10.
Yang, J., Jiang, Z., Fitzgerald, D. C., Ma, C., Yu, S., Li, H., Zhao, Z., Li, Y., Ciric, B., Curtis, M., Rostami, A., and Zhang, G. X. (2009). Adult neural stem cells expressing IL-10 confer potent immunomodulation and remyelination in experimental autoimmune encephalitis. J. Clin. Invest. 119, 3678-3691.

Yuan, A., Farber, E. L., Rapoport, A. L., Tejada, D., Deniskin, R., Akhmedov, N. B., and Farber, D. B. (2009). Transfer of microRNAs by embryonic stem cell microvesicles. PLoS ONE 4, e4722. doi:10.1371/journal.pone.0004722

Zhang, Y., Liu, D., Chen, X., Li, J., Li, L., Bian, Z., Sun, F., Lu, J., Yin, Y., Cai, X., Sun, Q., Wang, K., Ba, Y., Wang, Q., Wang, D., Yang, J., Liu, P., Xu, T., Yan, Q., Zhang, J., Zen, K., and Zhang, C. Y. (2010). Secreted monocytic miR-150 enhances targeted endothelial cell migration. Mol. Cell 39, 133-144.

Zhuang, X., Xiang, X., Grizzle, W., Sun, D., Zhang, S., Axtell, R. C., Ju, S., Mu, J., Zhang, L., Steinman, L., Miller, D., and Zhang, H. G. (2011). Treatment of brain inflammatory diseases by delivering exosome encapsulated anti-inflammatory drugs from the nasal region to the brain. Mol. Ther. 19, 1769-1779.

Zitvogel, L., Regnault, A., Lozier, A., Wolfers, J., Flament, C., Tenza, D., Ricciardi-Castagnoli, P., Raposo, G., and Amigorena, S. (1998). Eradication of established murine tumors using a novel cell-free vaccine: dendritic cell-derived exosomes. Nat. Med. 4, 594-600.

Ziv, Y., Avidan, H., Pluchino, S., Martino, G., and Schwartz, M. (2006). Synergy between immune cells and adult neural stem/progenitor cells promotes functional recovery from spinal cord injury. Proc. Natl. Acad. Sci. U.S.A. 103, 13174-13179.

Conflict of Interest Statement: The authors declare that the research was conducted in the absence of any commercial or financial relationships that could be construed as a potential conflict of interest.

Received: 12 March 2012; paper pending published: 28 March 2012; accepted: 11 April 2012; published online: 01 May 2012.

Citation: Cossetti C, Smith JA, Iraci $N$, Leonardi T, Alfaro-Cervello $C$ and Pluchino S (2012) Extracellular membrane vesicles and immune regulation in the brain. Front. Physio. 3:117. doi: 10.3389/fphys.2012.00117

This article was submitted to Frontiers in Membrane Physiology and Biophysics, a specialty of Frontiers in Physiology.

Copyright (C) 2012 Cossetti, Smith, Iraci, Leonardi, Alfaro-Cervello and Pluchino. This is an open-access article distributed under the terms of the Creative Commons Attribution Non Commercial License, which permits non-commercial use, distribution, and reproduction in other forums, provided the original authors and source are credited. 